\title{
LOOKING BACKWARDS INTO A MEDITERRANEAN EDGE ENVIRONMENT: \\ LANDSCAPE CHANGES IN EL CONGOST VALLEY (CATALONIA), 1850-2005
}

\section{ENRIC TELLO*}

\section{NATÀLIA VALLDEPERAS}

\section{ANNA OLLÉS}

University of Barcelona

Department of Economic History and Institutions

Faculty of Economics and Business

Diagonal 690

BARCELONA 08034, Spain

Email:tello@ub.edu; nataliavalldeperas@gmail.com; annaolles9@gmail.com

*Corresponding author

\section{JOAN MARULL}

\section{FRANCESC COLL}

Autonomous University of Barcelona

Barcelona Institute of Regional and Metropolitan Studies (IERMB)

Bellaterra Campus

Plaça Nord, Building MRA, floor 2

BELLATERRA (Cerdanyola del Vallès) 08193, Spain

Email:joan.marull@uab.cat; francesc.coll@uab.cat

\section{PAUL WARDE}

School of History

Faculty of Arts and Humanities

University of East Anglia

Norwich Research Park, NR4 7TJ, UK

Email:P.Warde@uea.ac.uk

\section{PAUL THOMAS WILCOX}

Freelance Environmental Scientist

Verge de Montserrat 22, 1으,

Figaró-Montmany 8590, Spain

Email:paulaswilcox@hotmail.com 


\section{ABSTRACT}

We examine the evolution from the mid-nineteenth century to the present of the cultural landscape in two Catalan townships that jointly constitute an edge environment between Mediterranean plain and mountain. This environmental edge has changed over time, from a border between an agricultural plain confronting an area of forestry and livestock-raising in the mid-nineteenth century, to a limit of the Barcelona Metropolitan Region confronting two 'natural' protected sites in the present. Over a century and a half land use changes in this area have brought about the two main, but superficially 'opposed' dynamics that characterise landscape evolution throughout Catalonia and great parts of Europe today: intensification and abandonment. The most salient ecological impact of both processes has been the loss of landscape mosaics. In the plain those mosaics interwove cereal cropping with vineyards and olive orchards together with patches of woodland, scrubland and pastureland into an agricultural land matrix. In the mountains, a woodland matrix of holm oaks and pines became cleared through timber and firewood extraction, and the pruning of branches for charcoal making, creating a mixture of open forest articulated by grazing areas, cropland and scrub. Both sides of the edge interlinked, and jointly played a key role as ecological connectors to maintain biodiversity. From the 1960s onwards the ecological dynamics attendant upon the abandonment of the prevailing integrated management of forests, livestock breeding and cropland has led to a significant loss of these landscape mosaics. In spite of the transformation of much of this area into natural protected sites, the growth of a uniform and continuous reforested woodland canopy, directly confronted with urban sprawl, is endangering its richness in terms of species - such as Mediterranean orchids, whose habitats are disappearing.

\section{KEYWORDS}

Land-use change, landscape mosaics, biodiversity, edge environment, Catalonia 
Over the last sixty years the prevailing landscape trends in the Mediterranean bioregion, as in many parts of Europe, have been the growth of urban sprawl and industrial sites related to transport, energy or communication networks, sometimes surrounded by rings of intensive and mechanised agriculture, while the rest of the land has tended to be increasingly abandoned and spontaneously reforested. ${ }^{1}$ Together, urban sprawl, agricultural intensification and rural abandonment jointly entail a severe loss of the agro-forest mosaics created in many traditional cultural landscapes, which have been increasingly praised by ecologists for their role in maintaining biodiversity. ${ }^{2}$

\footnotetext{
${ }^{1}$ Recent European land-use statistic and trends can be found in European Environment Agency, Land accounts for Europe 1990-2000. Towards Integrated Land and Ecosystem Accounting (Luxembourg: Office for Official Publications of the European Communities, 2006), http://www.eea.europa.eu/publications/eea report 2006 11; J.L. Weber, 'Implementation of land and ecosystem accounts at the European Environment Agency', Ecological Economics 61 (2007): 695-707; J. Feranec, G Jaffrain, T. Soukup and G. Hazeu, 'Determining changes and flows in European landscapes 1990-2000 using CORINE land cover data', Applied Geography 30 (2010): 1935-; and F. Gerard, S. Petit, G. Smith, A. Thomson, N. Brown, S. Manchester, R. Wadsworth, G. Bugar, L. Halada, P. Bezak, M. Boltiziar and E. De Badts, 'Land cover change in Europe between 1950 and 2000 determined employing aerial photography', Progress in Physical Geography 34 (2010): 183205-. Drivers and effects of this ongoing global change are discussed in W. Vos and H. Meeks, 'Trends in European cultural landscape development: perspectives for a sustainable future', Landscape and Urban Planning 46 (1999): 3-14-; M. Antrop, 'Changing patterns in the urbanized countryside of Western Europe', Landscape Ecology 15 (2000): 257-270-, and 'Landscape change and the urbanization process in Europe', Landscape and Urban Planning 67 (2004): 9-26-; E.F. Lambin and H. Geist (eds) Land-use and Land-cover Change: Local Processes and Global Impacts (Berlin: Springer, 2006).

2 The environmental role of agro-forest mosaics was pointed out, among others, in R. Margalef, 'Ecological Theory and Prediction in the Study of the Interaction between Man and the Rest of Biosphere', in H. Siolo (ed.) Ökologie und Lebensschutz in Intrenationaler Sicht (Freiburg: Rombach, 1973; reprinted in Medi Ambient. Tecnologia i Cultura 38 (2006): 114-125-; http://mediambient.gencat.net/cat/el departament/revista/38/sumario ingles.jsp; M. Giampietro, 'Socioeconomic constraints to farming with biodiversity', Agriculture, Ecosystems \& Environment 62 (1997): 145-167-; and T.G. Benton, J.A. Vickery and J.D. Wilson, 'Farmland biodiversity: is habitat heterogeneity the key?' Trends in Ecology and Evolution 18 (2003): 182-188-; for the same approach applied to Catalan case studies see J. Marull, J. Pino and E. Tello, 'The Loss of Landscape Efficiency: An Ecological Analysis of Land-Use Changes in Western Mediterranean Agriculture (Vallès County, Catalonia, 1853-2004)', Global Environment. Journal of History and Natural and Social Sciences 2 (2008): 112-150; and J. Marull, J. Pino, E. Tello and M.J. Cordobilla, 'Social metabolism, landscape change and land-use planning in the Barcelona Metropolitan Region', Land Use Policy 27 (2010): 497-510. For the new approaches to cultural landscapes see A. Farina, 'Recent changes of the mosaic patterns in a montane landscape (north Italy) and consequences on vertebrate fauna', Options Méditerranéennes 15 (1991): 121-134; A. Farina, A.R. Johnson, S.J. Turner and A. Belgrano, "Full" world versus "empty" world paradigm at the time of globalisation', Ecological Economics 45 (2003): 11-18; M. Agnoletti (ed.) The Conservation of Cultural Landscapes (Wallingford: CABI Pub., 2006) and Paesaggi Rurali Historici. Per un Catalogo Nazionale/Historical Rural Landscapes. For a National Register (Roma-Bari: Laterza, 2010). For the environmental landscape degradation, see D. Schröter, W. Cramer, R. Leemans et al., 'Ecosystem service supply and vulnerability to global change in Europe', Science 310 (2005): 1333-1337.
} 
Since these landscape mosaics come from human intervention in ecosystems, while at the same time retaining functioning natural processes within them, they become a kind of nature transformed. In order effectively to manage and preserve them we need a historical perspective to understand the magnitude, causes and consequences of these interlinked social and natural processes. Even more, recovering the historical dynamics behind our current land-use patterns becomes a necessity for more encompassing, complex and multidimensional approaches to sustainable landscapes. This landscape history research has to be addressed on different geographical scales and time spans by interdisciplinary teams like the one assembled here - which includes two historians, a biologist, an architect, a geographer and two environmental scientists. ${ }^{3}$ Given the dual nature of cultural landscapes, both human-made and natural patterns, the loss of agro-forest mosaics also implied a decline of knowledge about managing natural resources in an integrated manner. The increasing apparent homogeneity of these abandoned landscapes is making the relicts of previous ecologies harder to discern (and more easy to degrade) in a society where the local inhabitants have less and less information on, or interaction with, them. ${ }^{4}$

Behind these trends are three major driving forces summarised by Marc Antrop for the whole of Europe: accessibility, urbanisation and globalisation. Accessibility has to be understood not only as physical transport or cultural connection, but as the increasing purchasing power of goods and services as well.

\footnotetext{
${ }^{3}$ For the new approaches to sustainable landscapes see A. Farina, "The Cultural Landscape as a Model for the Integration of Ecology and Economics', BioScience 50 (2000): 313-320; M. Antrop, 'Sustainable landscapes: contradiction, fiction or utopia?', Landscape and Urban Planning $\mathbf{7 5}$ (2006): 187-197; R. Matthews and P. Selman, 'Landscape as a focus for integrating human and environmental processes', Journal of Agricultural Economics 57 (2006): 199-212; and M. Rössler, 'World heritage cultural landscapes: a UNESCO flagship programme 1992-2006', Landscape Research 31 (2006): 333-353.

${ }^{4}$ F. Berkes and C. Folke, 'Back to the Future: Ecosystem dynamics and Local Knowledge', in L.H. Gunderson and C.S. Holling (eds) Panarchy. Understanding Transformations in Human and Natural systems (Washington: Island Press, 2002), pp. 121-146; J. Parrotta and M. Agnoletti, "Traditional forest knowledge: challenges and opportunities, Forest Ecology Management 249 (2007): 1-4; and P. Meyfroidt, 'Environmental cognition, land change, and Social-ecological feedbacks. An overview', Journal of Land Use Science 8 (2013):341-367; see also recent studies made in Spain from this perspective: E. Gómez-Baggethun, V. Reyes-García, P. Olsson and C. Montes, 'Traditional ecological knowledge and community resilience to environmental extremes', Global Environmental Change 22 (2012):640-650; M. Boada, 'Sostenibilidad y cultura campesina: hacia modelos alternativos de desarrollo rural. Una propuesta desde Cataluña', Boletín de la Asociación de Geógrafos Españoles 41 (2006): 315-328; and I. Otero, M. Boada and J.D. Tàbara, 'Social-ecological heritage and the conservation of Mediterranean landscapes under global change. A case study in Olzinelles (Catalonia)', Land Use Policy 30 (2013): 25-37.
} 
At the beginning of the twenty-first century, easy market access to natural resources at almost any place in a globalised world has led to some levelling of the standard of living across the metropolitan hinterlands of developed countries, far from the former sharp divides between cities, towns and rural villages. In our case study area the average taxable household income in the two townships that we study, La Garriga and Figaró-Montmany, is near to the average GDP per capita in the fifteen countries of the Eurozone: some $€ 28,400$ at 2008 prices (Table 1). ${ }^{5}$ However, the situation was very different just fifty years ago, both in comparing the townships with each other, and with the wider European experience - as discussed below.

Table 1. Socioeconomic profiles of the study area at the beginning of the twentyfirst century

\begin{tabular}{|l|r|r|r|}
\hline & La Garriga & \multicolumn{1}{l|}{$\begin{array}{l}\text { Figaró- } \\
\text { Montmany }\end{array}$} & Catalonia \\
\hline Inhabitants (2011) & 15,236 & 1,112 & $7,539,618$ \\
Inhabitants/km² (2011) & 810.4 & 74.1 & 990.7 \\
Average taxable income per household & 22,997 & 19,840 & 20,843 \\
(in €, 2007) & 24,700 & n.a. & 29,160 \\
GDP/inhabitant (in €, 2008) & & \\
\hline
\end{tabular}

Sources: Taken from IDESCAT (http://www.idescat.cat/en/) and EUROSTAT (http://epp.eurostat.ec.europa.eu/portal/page/portal/eurostat/home/).

In the following sections we will describe how accessibility, the rural-urban divide, metropolitan networks and globalisation combined in different proportions as historical driving forces for land-use changes in the study area from the midnineteenth century to the beginning of the twenty-first century. Throughout this environmental history these local landscapes experienced some long-term continuities, but also several deep discontinuities and big accelerations at specific turning points. The most important of these was, no doubt, the land-use changes fostered by the urbanisation and globalisation experienced during the second half

5 M. Antrop, 'Why landscapes of the past are important for the future', Landscape and Urban Planning 70 (2005): 21-34. 
of the twentieth century. Nevertheless, a longer-term perspective helps to identify the agro-ecological roots of the traditional cultural landscape and its environmental services that have been undermined by the fast-growing industrial economy during the era of cheap oil. ${ }^{6}$

This environmental history of land-use changes has been as complex and multidimensional as cultural landscapes are themselves. The changes range from the substitution of former land cover with newer types, to human perceptions of these, or the senses of identity adopted by the communities who have altered their land usages, consumption baskets and ecological imprints over time. In the rest of this article we will focus on how land cover changes between 1854 and 2005 have affected ecological patterns in these landscapes, and their capacity to host biodiversity. ${ }^{7}$

\section{MAIN FEATURES OF OUR CATALAN STUDY AREA}

\section{Location}

Edge environments show ongoing environmental processes in a particularly dramatic light, partly because they help highlight the existence of earlier, more diverse and integrated landscapes as being characterised by the very prevalence of smaller 'edges' within them. ${ }^{8}$ The two Catalan townships studied are currently

\footnotetext{
${ }^{6}$ Ch. Pfister, "The "1950s Syndrome" and the Transition from a Slow-Going to a Rapid Loss of Global Sustainability', in F. Uekoetter (ed.) The Turning Points of Environmental History (Pittsburgh: University of Pittsburgh Press, 2010) pp. 90-118.

${ }^{7}$ On the complexity of landscapes see Z. Naveh, 'Interactions of landscapes and cultures', Landscape and Urban Planning 32 (1995): 43-54, and 'Ten major premises for a holistic conception of multifunctional landscapes', Landscape and Urban Planning 57 (2001): 269-284, as well as B. Tress, G. Tress, H. Décamps and A.M. d'Hauteserre, 'Bridging human and natural sciences in landscape research', Landscape and Urban Planning 57 (2001): 137-141. For the linkages between changing living standards and their historical ecological imprints, see G. Billen, J. Garnier and S. Barles, 'History of the urban environmental imprint: introduction to a multidisciplinary approach to the long-term relationships between Western cities and their hinterland', Regional Environmental Change 12 (2012): 249-253; and K.P. Donaghy, 'Urban environmental imprints after globalisation', Regional Environmental Change 12 (2012): 395-405.

${ }^{8}$ We are using in the title and in this introductory section a geographical-wide meaning of 'edge environment', a notion that needs to be distinguished from the ecological 'edge effect' in ecotones seen on a smaller land-cover scale - as discussed below. In the same vein, William Cronon spoke in Changes in the Land: Indians, Colonists and the ecology of New England about the patchwork pattern of the New England pre-colonial landscape as mainly determined by topography (slopes, exposition or aspect, etc.) seen in a geographical scale, and then also about the ecological 'edge effect' looked at on a smaller scale, as in the clearing of forest patches made by the Indians through controlled fires (New York: Hill and Wang, 2003, pp. 25-33 and 51).
} 
located at the very edge of the Barcelona Metropolitan Region (BMR), situated in one of the few North-South axes that for many centuries have connected the coastal area of Barcelona to the Pyrenees. Following this axis along the township of Figaró-Montmany, the river Congost runs North to South through a small gorge between the massif of El Montseny and the cliffs and crags of the Cingles de Bertí. The southern limit of the gorge ends where the Congost River reaches the neighbouring township of La Garriga, opening to the Vallès plain located between the pre-littoral and littoral mountain ranges of Catalonia. There, it drains its tributary flow to the Besòs River. (Figure 1). 
Figure 1. Location of the study area in Catalonia, the Barcelona Metropolitan Region and the main transport routes along the rivers - showing the railways built in 1900.

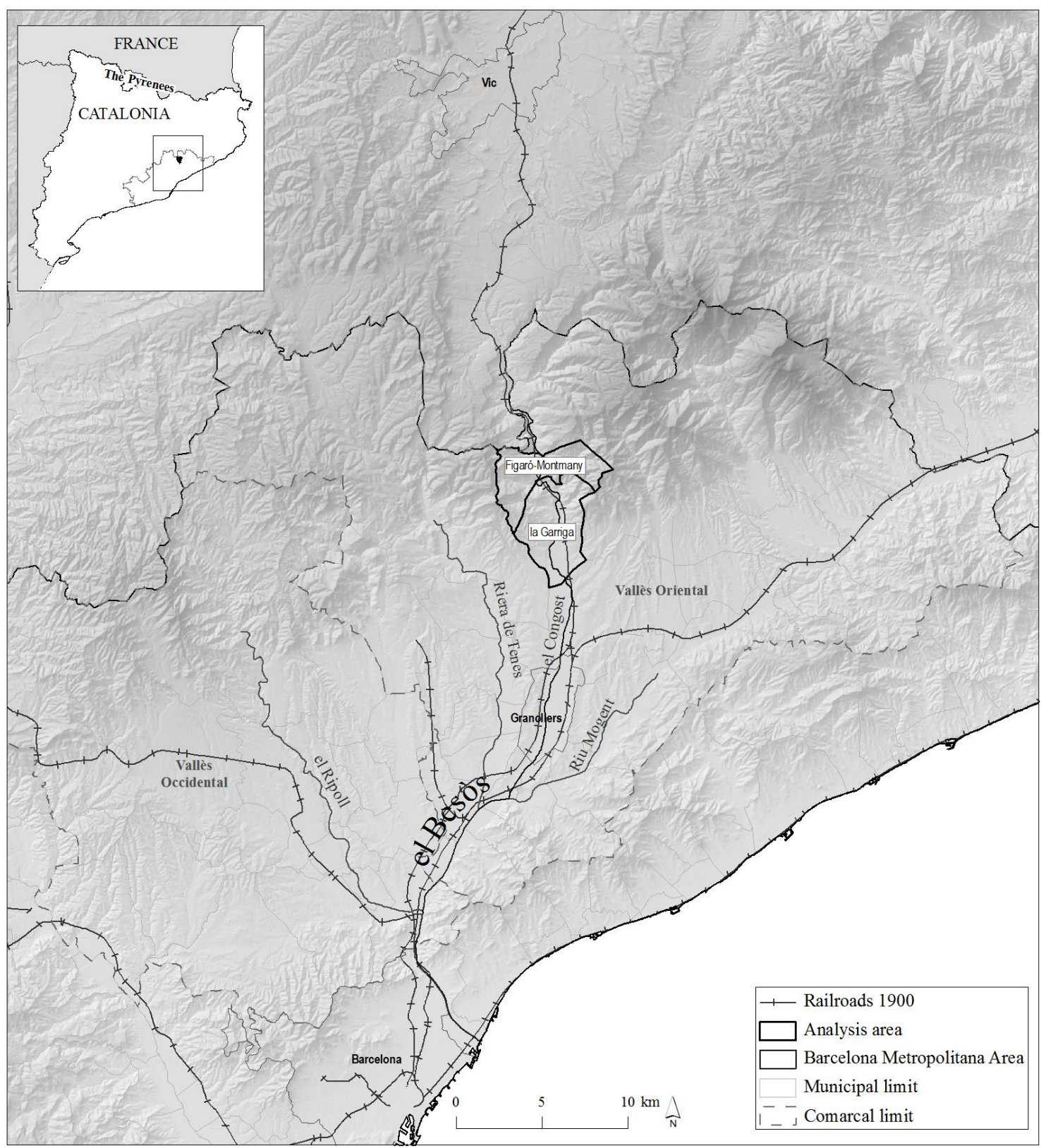

Sources: Drawn at the IERMB, with its own historical dataset on railroads and other transport facilities.

The Congost valley was traversed by a Roman road and medieval royal routes linking the Catalan littoral with the South of France, a small example of the old-age interconnectivity among different Mediterranean micro-regional environments - 
diverse natural endowments created within the same bioregion by different gradients of altitude, proximity to the sea, slopes and sunny or shady sides of the land, and the relative abundance or shortage of water. In interaction with settlement patterns, population densities and institutional settings these provided complementary economies. Starting in the harbour of Barcelona, and following the same route, the railway reached the inland town of Vic in 1875 and the Pyrenees in 1880. Then, during the 1970s the old cart-road was turned into a highway up to Vic. These transport facilities linked the rural economy of our study area with coastal urban markets from an early date. Commercial linkages intensified during the processes of industrialization, urbanization and globalization from the second half of the nineteenth century. ${ }^{9}$

Two paths of population growth

Both municipalities reacted to these market stimuli in very different ways. La Garriga evolved in a similar way to the adjacent Vallès plain. Vineyards spread and mixed with cereal cropland and small woodlands in an agro-forest mosaic that extended from the irrigated orchards surrounding the Congost River up to the forests and pastures in the nearby mountains. In 1858 vineyards occupied a great proportion of cultivated land in Figaró-Montmany too, in fact it was the northern limit of this crop at that time within the province of Barcelona. Nevertheless most of the municipality's steep and elevated land was devoted to woodland, scrubs and pasture. ${ }^{10}$

\footnotetext{
9 The idea of interconnected micro-regional environments is taken from P. Horden and N. Pourcell, The corrupting sea. A study of Mediterranean history (London: Blackwell, 2008). They express the same idea with the term 'microecologies', which is a rather confusing term from a natural science standpoint (as microecology is the study of the interactions between microorganisms and their environment).

10 We have studied the vineyard specialization in this Catalan region in X. Cussó, R. Garrabou and E. Tello, 'Social metabolism in an agrarian region of Catalonia (Spain) in 1860-70: flows, energy balance and land use', Ecological Economics 58 (2006): 49 - 65; X. Cussó, R. Garrabou, J.R. Olarieta and E. Tello, 'Balances energéticos y usos del suelo en la agricultura catalana: una comparación entre mediados del siglo XIX y finales del siglo XX', Historia Agraria 40 (2006): 471 - 500; E. Tello, R. Garrabou and X. Cussó, 'Energy Balance and Land Use: The Making of and Agrarian Landscape from the Vantage Point of Social Metabolism (the Catalan Vallès County in 1860/70)', in M. Agnoletti (ed), The Conservation of Cultural Landscapes, 42-56; R. Garrabou, E. Tello, X. Cussó and M. Badia-Miró, 'Explaining agrarian specialization in an advanced organic economy: The province of
} 
While the rural economy of La Garriga became mainly horticultural and agricultural, that of Figaró-Montmany remained mainly oriented to lumbering, firewood extraction, charcoal making and livestock breeding. The neighbouring northern townships also provided snow or ice collected in the Montseny Mountains and stored in ice wells dug in the land to be sold in Barcelona and other nearby cities in order to cool beverages and food. According to the Land-Use Statistics of the Province of Barcelona compiled in 1858 the taxable value-added of one acre of cropland in La Garriga was double that in Figaró-Montmany - the former was 42 per cent above the average in the East Vallès County, the latter was 31 per cent below. ${ }^{11}$

The nucleated habitat of the village in La Garriga also contrasted with the scattered farms of Figaró-Montmany, where most inhabitants lived in lateral valleys near the most important resources: woods, pastures, watercourses and snow. Only a few houses and three inns on the old royal road clustered by the Congost River. The traditional name of the township was then Montmany de Puiggraciós and Vallcàrquera, after the two main side valleys inhabited by cattle breeders, lumberjacks and charcoal makers. The official name changed in the last quarter of the nineteenth century with the arrival of the railway, taking Figaró from the name of the main inn. Thereafter most new houses clustered around the railway stop, while many isolated farm dwellings became abandoned.

Manufacturing also evolved in opposite ways in the two villages. Traditional as well as modern textile industries, and furniture making were developed in La Garriga. In Figaró-Montmany manufacture remained small, hand-powered and tightly linked to the raw materials locally available such as sawmills, cutting clogs and wooden planks, stone slabs for floors and fireplaces, or charcoal making. In 1852 La Garriga had one taxpayer in industrial or commercial activities for every five agricultural ratepayers, compared to one for every nine in Figaró-Montmany.

\footnotetext{
Barcelona in mid-nineteenth century', in V. Pinilla (ed), Markets and Agricultural Change in Europe from the Thirteenth to the Twentieth Century (Turnhout: Brepol Pub., 2009), 137-172; and R. Garrabou, E. Tello and X. Cussó, 'Ecological and Socio-economic functioning of the Mediterranean agrarian systems in the middle of the nineteenth century. A Catalan case study (the Vallès county, 1850-70)', in E. Landsteiner and E. Langthaler (eds), Agrosystems and Labour Relations in European Rural Societies (Middle Ages-20th Century), (Turnhout: Brepols Pub., 2010), 119-152.

11 Published by J.I. Muro, F. Nadal and L. Urteaga (eds), Estadística Territorial de la Provincia de Barcelona 1858 (Barcelona: Societat Catalana de Geografia/Institut d'Estudis Catalans, 2011).
} 
La Garriga's payment of commercial and industrial taxes was ten times higher than its mountain neighbour's, five times on a per capita basis. ${ }^{12}$ Consequently, population and income growth followed diverging paths. In 2010 the number of inhabitants of Figaró-Montmany was only 52 per cent higher than in 1860, whereas in La Garriga increased tenfold (Figure 2).

FIGURE 2. Populations trends in La Garriga and Figaró-Montmany, 1857-2010

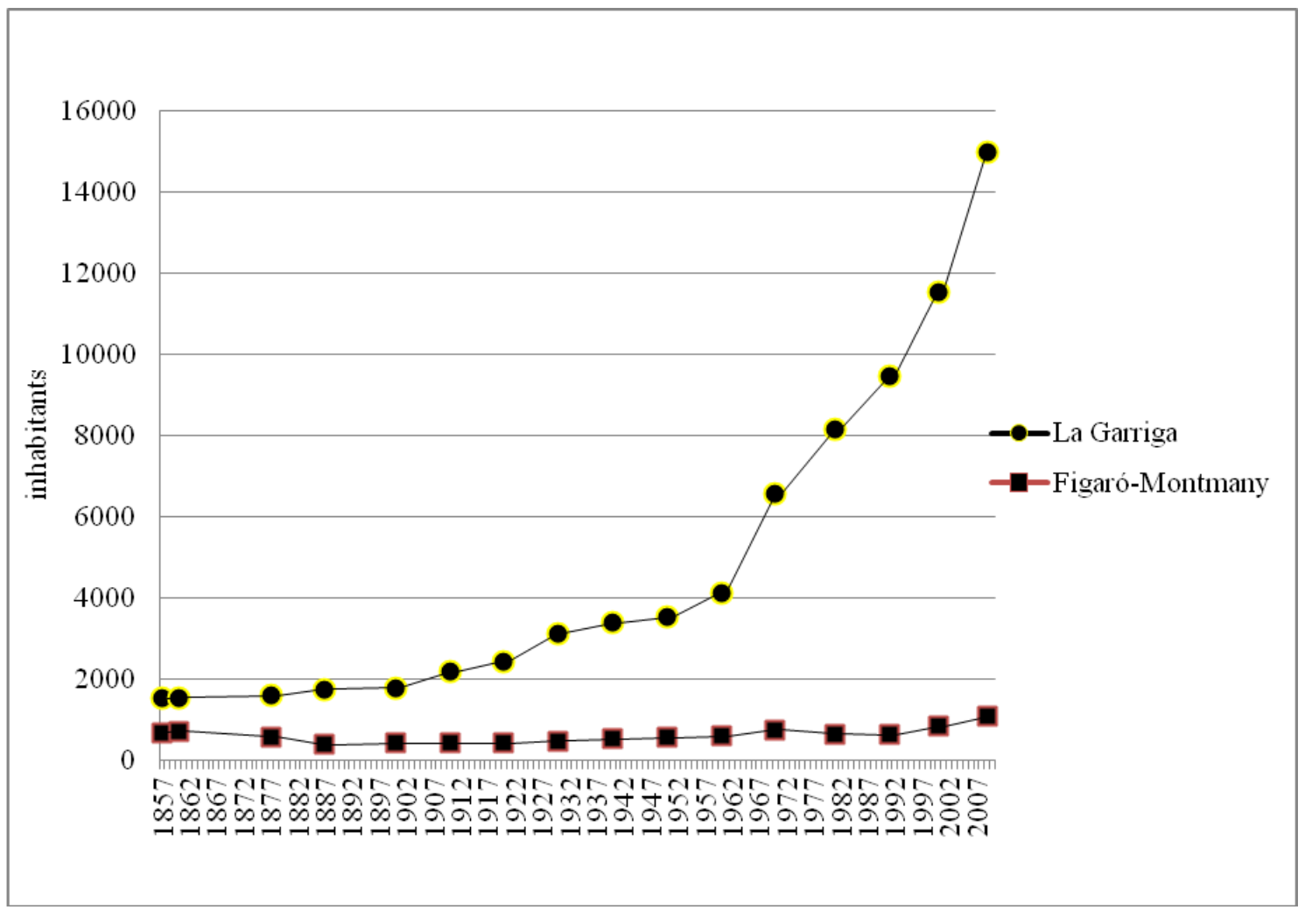

$\begin{array}{llll}\text { Sources: } & \text { Taken } & \text { from } & \text { Centre Estudis Demogràfics }\end{array}$

(http://www.ced.uab.es/index.php).

\section{A long-lasting wealth divide}

While La Garriga became a wealthier town that attracted affluent newcomers as residents and investors, Figaró-Montmany remained a poorer rural provider of

\footnotetext{
${ }^{12}$ According to the Parte Industrial y de Comercio of the taxpayer's lists published as a supplement of the Official Gazette of the Province of Barcelona the $20^{\text {th }}$ of April of 1852, kept in the library of the University of Barcelona, reference 146-1-II/13 box III.
} 
mainly organic energy carriers: wood, charcoal and meat. As seen in Table 2, in 1857 population density was nearly two times greater in La Garriga (80.7 inhabitants $/ \mathrm{km}^{2}$ ) than in Figaró-Montmany (42.7). Cultivated land occupied 56 per cent of the useful surface of La Garriga, and woodlands, scrublands or pasturelands only 44 per cent. The opposite was true in Figaró-Montmany: in 1858 only 28 per cent was devoted to crops and 72 per cent was woods, scrubs and pastures. In 1852 the total net taxable income coming from agricultural, forestry and livestock breeding was more than four times higher in La Garriga than in Figaró-Montmany, and nearly two times higher in per capita terms. Inequality in the wealth distribution of land, houses and livestock was also higher in La Garriga (with a Gini Index of 0.743 ) than in Figaró-Montmany $(0.601) .{ }^{13}$ In both places the land was mainly owned by a group of small or medium-size family farms (called masies in Catalan) that leased small plots and hired labour from landless peasants. ${ }^{14}$

\footnotetext{
13 The Gini index measures the inequality among values of a frequency distribution of levels of income or wealth, moving between zero (when everyone has an exactly equal income or wealth) and one (that expresses maximal inequality).The 1852 tax lists referred in the previous footnote evaluated the land, houses and livestock assets of every taxpayer through its net taxable income in an average year, excluding other family incomes coming from wages or domestic manufacturing activities. Therefore, these Gini indices reflect agricultural wealth distribution, as explained in E. Tello and M. Badia-Miró, Land-use profiles of agrarian income and land ownership inequality in the province of Barcelona in mid-nineteenth century, Working Paper DT-SEHA n. 11-01. It is worth noting that the lower rural wealth inequality found in Figaró-Montmany compared with La Garriga contradicted the opposite pattern prevailing in the whole province of Barcelona, as shown in the aforementioned working paper.

${ }^{14}$ As many places in the North-East of Catalonia, the distribution of land ownership that arose from liberal reforms during the nineteenth century consolidated a previously existing structure of medium-size poly-cultural family farms ranging from some five to fifty hectares each - mainly depending on the more intensive or extensive uses of the land inside them. As population grew and commercial ties with the Atlantic economy developed, these medium-sized landowners started to lease small plots of poor sloping soils to a growing stratum of winegrower tenants. This process of market specialization and land-use intensification polarized rural society, which saw lasting social conflict up to the Spanish Civil War. After the repression and impoverishment suffered during the first decades of Franco's dictatorship, rapid economic upswing started in the sixties putting an end to the old dispute about land entitlements and agricultural income distribution. Again a pattern of small and medium-size family farms prevailed, increasingly managed part-time as agriculture became a more marginal economic activity.
} 
TABLE 2. Socioeconomic features of the study area in the mid-nineteenth century

\begin{tabular}{|c|c|c|c|}
\hline & $\begin{array}{l}\text { La } \\
\text { Garriga }\end{array}$ & $\begin{array}{l}\text { Figaró- } \\
\text { Montmany }\end{array}$ & $\begin{array}{l}\text { province of } \\
\text { Barcelona }\end{array}$ \\
\hline \multicolumn{4}{|l|}{$\mathrm{km}^{2}$} \\
\hline \multicolumn{4}{|l|}{ Inhabitants (1857) } \\
\hline \multicolumn{4}{|l|}{ Inhabitants $/ \mathrm{km}^{2}$ (1857) } \\
\hline \multicolumn{4}{|l|}{ Cropland acreage (has 1858) } \\
\hline \multicolumn{4}{|l|}{ Cropland has/inhabitant (1857-1858) } \\
\hline \multicolumn{4}{|l|}{ Land sown with cereals (has 1858) } \\
\hline \multirow{2}{*}{$\begin{array}{l}\text { Land sown with cereals/inhabitant (has 1857- } \\
\text { 1858) }\end{array}$} & 80.7 & 42.7 & 92.9 \\
\hline & 898.3 & 438.5 & $224,256.5$ \\
\hline \multicolumn{4}{|l|}{ Vineyards acreage (has 1858) } \\
\hline \multicolumn{4}{|l|}{ Vineyards/inhabitant (1857-1858) } \\
\hline \multicolumn{4}{|l|}{ Woodland \& pasture acreage (has 1858) } \\
\hline Woods \& pasture/inhabitant (1857-1858) & 504.8 & 245.4 & $114,162.8$ \\
\hline \multirow{2}{*}{$\begin{array}{l}\text { Coverage rate of cereal consumption by local } \\
\text { production }(\% 1858-1867)\end{array}$} & 0.33 & 0.36 & 0.16 \\
\hline & 708.5 & $1,145,3$ & $444,040.2$ \\
\hline \multirow{2}{*}{$\begin{array}{l}\text { Agricultural wealth estimated by the cadastre } \\
\text { (Spanish reales of 1852) }\end{array}$} & 0.47 & 1.69 & 0.63 \\
\hline & 32.3 & 54.7 & 38.6 \\
\hline $\begin{array}{l}\text { Taxable agricultural wealth/inhabitant } \\
\text { (Spanish reales in 1852-1857) }\end{array}$ & 389,667 & 91,239 & $106,164,548$ \\
\hline \multirow{2}{*}{$\begin{array}{l}\text { Gini index of inequality in agricultural wealth } \\
\text { distribution (1852) }\end{array}$} & 256.7 & 135.0 & 150.2 \\
\hline & 0.743 & 0.601 & 0.682 \\
\hline
\end{tabular}

Sources: Population figures taken By Enric Tello from the Centre d'Estudis Demogràfics; land uses from the Land-Use Statistics in the Province of Barcelona; taxable agricultural incomes from the Distribution of Personal Income from Real Estate Ownership in 1852 and E. Tello and M. Badia-Miró, Land-use profiles of agrarian income and land ownership inequality in the province of Barcelona in mid-nineteenth century, Working Paper DT-SEHA n. 11-01, http://ideas.repec.org/p/seh/wpaper/1101.html; and coverage rate of cereal consumption for local production from R. Garrabou, X. Cussó and E. Tello, 'La persistència del conreu de cereals a la província de Barcelona a mitjan segle XIX', Estudis d'Història Agrària 20 (2007): 185, 196. 
Thus in the mid-nineteenth century the township border between La Garriga and Figaró-Montmany was already an edge environment between two agro-ecological worlds: the intensive and poly-cultural agriculture of the plain of Vallès County; and on the other hand the multiple and integrated use of woodlands, scrub and pastures of the slopes, hills and small valleys along the Catalan pre-littoral mountains. According to the statistics from 1858-1867, the average share of cereal consumption covered by local production was only 32.3 per cent in La Garriga and 54.7 per cent in Figaró-Montmany - while in the whole province of Barcelona the average was 38.6 per cent. The rest was supplied by wheat imports from Barcelona's seaport, in return for exports of wine, hemp, vegetables, cattle, wood, charcoal or snow. Therefore, these two small rural communities were far from an isolated and autarkic world. ${ }^{15}$

\section{Livestock densities and manure flows in a still organic agricultural system}

Another salient feature of these two contrasting worlds was the livestock densities on each side of the border. With only 6 livestock units of $500 \mathrm{~kg}$ of standardized live weight per square kilometre of cropland (LU500/ $\mathrm{km}^{2}$ ), the intensive agricultural system of La Garriga lacked sufficient beasts to obtain through manure all the nutrients needed for the replenishment of cultivated land, as was then often the case on the Vallès Plain. In contrast, thanks to the small proportion of cropped land and the larger herds grazing in pasturelands and forests, in 1858 FigaróMontmany had a livestock density per unit of cropland as high as $21 \mathrm{LU} 500 / \mathrm{km}^{2}$ (Table 2) - although some of these were horses used for hauling carts along the road. 16

\footnotetext{
15 The cultivation of hemp and vegetables was pointed out in the descriptions of La Garriga township given in V. de Frigola, Relación de los pueblos de que consta el Principado de Cataluña, and P. Madoz, Diccionario geográfico-estadístico-histórico de España y sus posesiones de ultramar, (Madrid: Est. Tipográfico-Literario Universal, Tomo VIII, 1847), 322. In Figaró-Montmany the same Diccionario geográfico-estadístico stressed the forestry and livestock breeding activities in the mountains and the inns in the gorge (Tomo XI, 1848), 506.

16 Most of the horses recorded in Figaró-Montmany were probably employed in the post service and in hauling carts along the route between Barcelona, Granollers and Vic towards the Pyrenees.
} 
TABLE 3. Livestock heads and densities in La Garriga and Figaró-Montmany in 1858

\begin{tabular}{|c|c|c|c|c|c|}
\hline & \multicolumn{2}{|l|}{ heads } & \multirow{2}{*}{$\begin{array}{l}\text { average } \\
\text { live } \\
\text { weights } \\
\text { per head } \\
\text { in } \mathrm{kg}^{*}\end{array}$} & \multicolumn{2}{|c|}{ live weights } \\
\hline & $\begin{array}{l}\text { La } \\
\text { Garriga }\end{array}$ & $\begin{array}{l}\text { Figaró- } \\
\text { Montmany }\end{array}$ & & $\begin{array}{l}\text { La } \\
\text { Garriga }\end{array}$ & $\begin{array}{l}\text { Figaró- } \\
\text { Montmany }\end{array}$ \\
\hline Horses & 3 & 59 & 326 & 978 & 19,234 \\
\hline Mules & 34 & 4 & 326 & 11,084 & 1,304 \\
\hline Donkeys & 4 & 15 & 172 & 688 & 2,580 \\
\hline Cows and oxen & 10 & 25 & 371 & 3,710 & 9,275 \\
\hline Sheep & 212 & 312 & 30 & 6,360 & 9,360 \\
\hline Goats & 11 & 82 & 34 & 374 & 2,788 \\
\hline Pigs & 50 & 14 & 77 & 3,850 & 1,078 \\
\hline TOTAL $^{* *}$ & 324 & 511 & & 27,044 & 45,619 \\
\hline \multicolumn{4}{|l|}{ LU500 } & 54.1 & 91.2 \\
\hline \multicolumn{4}{|c|}{ Useful Agricultural Area $\left(\mathrm{km}^{2}\right)$} & 16.1 & 15.8 \\
\hline \multicolumn{4}{|c|}{ LU500/ $\mathrm{km}^{2}$ of useful agricultural area } & 3.4 & 5.8 \\
\hline \multicolumn{4}{|c|}{ Cropland area $\left(\mathrm{km}^{2}\right)$} & 9.0 & 4.4 \\
\hline \multicolumn{4}{|c|}{ LU500/ $/ \mathrm{km}^{2}$ of cropland area } & 6.0 & 20.8 \\
\hline
\end{tabular}

Notes:

* Live weights per head are taken from E. Tello, R. Garrabou, X. Cussó, J.R. Olarieta and E. Galán, 'Fertilizing methods and nutrient balance at the end of traditional organic agriculture in the Mediterranean bioregion: Catalonia (Spain) in the 1860s', Human Ecology 40 (2012): 369 - 3.

** Chickens, rabbits and transhumant sheep are not included.

During the preindustrial 'solar' or 'organic' economy the three inns located in the gorge of this township were strategically placed at one-day's journey from Barcelona, and half a day to Vic (see Figure 1) according to V. Frigola, Relación de los pueblos de que consta el Principado de Cataluña, and Anonymous, Itinerario de la mayor parte de caminos y veredas de las cuatro provincias de Barcelona, Tarragona, Lérida y Gerona, con los pueblos y posadas situadas en sus carreras, y las horas que á paso de tropa distan unos de otros (Barcelona: Imprenta de Manuel Texero, 1838). When in 1854 the train reached the city of Granollers, the railways soon started carrying the loaded carts themselves from Barcelona to Granollers in nearly one hour thus allowing them to attain the city of Vic in one day. The resulting relocation of the need for fresh horses may explain the sharp reduction in the subsequent livestock censuses of Figaró-Montmany. The construction of Catalan railways and their impact is explained in P. Pascual, Los caminos de la era industrial: la construcción y financiación de la Red Ferroviaria Catalana (1843-1989) (Barcelona: Edicions Universitat de Barcelona, 1999). For the relevance of this things in an 'organic' or 'solar' economy, see R.P. Sieferle, The Subterranean forest: energy systems and the Industrial Revolution (Cambridge: The White Horse Press, 2001). 
Sources:

Taken by Enric Tello from the Land-Use Statistics in the Province of Barcelona.

It is likely that some manure collected in Figaró-Montmany was sold to fertilize the more intensive crops grown in irrigated lands in La Garriga, such as hemp and vegetables. At the same time pasturelands existing in La Garriga were probably leased in exchange for manure, either to livestock coming from neighbouring townships or transhumant sheep. These are good examples of the socio-metabolic flows linking both sides of this edge environment, while both townships participated at the same time in other biophysical fluxes moving along broader commercial routes.

Back-to-nature vacationers at the beginning of the $20^{\text {th }}$ century

These different but complementary land-use patterns began to change at the end of the nineteenth century when well-to-do urban elites started to look for cooler places to spend their leisure time during summer vacations, such as the foothills of the Montseny Mountains. La Garriga was favoured as a location for second homes by some of these wealthy families because it had thermal waters and several old spa-hotels that also allowed a longer stay in winter. Others preferred the cooler gorge of the Congost River in Figaró-Montmany. ${ }^{17}$

These summer vacations also led to a Romantic and nationalistic rediscovery of 'wild nature' in the landscapes that already existed behind the

\footnotetext{
${ }^{17}$ Leisure as such was not a novelty of that time, as pointed out by J.-Ll. Marfany, 'The Invention of Leisure in Early Modern Europe', Past \& Present 156 (1997):174 - 197. But the family summer vacations in the countryside do became a new urban habit for a wider range of high and middle classes of the time. See J.-Ll. Marfany, La cultura del catalanisme: el nacionalisme català en els seus inicis (Vic: Empúries, 1995), and Marfany, 'El paissatge, el nacionalisme i la Renaixença', Estudi General 13 (1993): 81 - 97; and J. Nogué and J. Vicente, 'Landscape and national identity in Catalonia', Political Geography 23 (2004): 113 - 132.
} 
urban backs of Catalan elites and intellectuals. Hiking, climbing and the study of rural life became fashionable activities at this time, not only among some affluent professionals but also proletarian families educated by the working-class athenaeums in the libertarian ideals of emancipation as well - which in Catalonia were increasingly mixed with vegetarian and naturalist undercurrents. Lying only one hour by train from Barcelona, Figaró-Montmany became popular for hiking, climbing and cycling and as a gateway to the Montseny and Cingles de Bertí mountains. ${ }^{18}$

During the first third of the twentieth century investments in second homes opened up new tertiary employment opportunities for local people: as maids, laundresses, seamstresses, nannies, gardeners, plumbers and so on. At the same time the cultural mixing with different back-to-nature intellectual and social movements also led to an increasing adoption of the ideas of nature conservation, tightly linked in Catalonia to new proposals for city-gardens, green belts and regional planning. In 1932 the Catalan autonomous government published a Regional Plan of Catalonia which categorised the Montseny massif as an 'area of reserved parks and forests' surrounded on its North-East border by a 'grazing area'. ${ }^{19}$

\section{A late conversion into nature protected sites}

However the pioneering attempt at land-use planning during the Second Republic was abruptly stopped by the Francoist dictatorship after the Spanish Civil War (1936-1939). The effective protection of the Montseny (1977) and the Cingles de Bertí (2002) areas only arrived after the death of the dictator (1975) and the restoration of democracy in Spain. Conversion into natural protected sites

\footnotetext{
${ }^{18}$ For the connections of the Catalan anarchism with naturism, vegetarianism, nudism and the citygarden movement, see J. Martínez Alier, 'Urban sprawl and ecology in Barcelona', Temes de disseny 11 (1995): $\quad 53 \quad$ - $\quad 95 \quad$ (available at http://www.raco.cat/index.php/Temes/article/view/29437/50910), and E. Masjuan, La ecología humana en el anarquismo ibérico (Barcelona: Icaria 2000).

19 The map of the first Catalan Regional Planning passed in 1932 can be seen in http://cartotecadigital.icc.cat/cdm/singleitem/collection/catalunya/id/1112/rec/5.
} 
happened when these landscapes were already experiencing one of the most fundamental shifts in their long environmental history.

The new era of cheap oil in the 1960s saw the diffusion of gas butane cylinders, putting a sudden end to local charcoal making. Lorry transportation allowed the delinking of the small cluster of furniture makers located in La Garriga and L'Ametlla de Vallès from their former supply of planks in Figaró-Montmany. Industrialization of agriculture during the so-called Green Revolution led to the abandonment of steep slopes where mechanization was most difficult. As happened in many other European regions, new intensive monocultures and the breeding of livestock in industrial feed-lots were adopted in the plains, leading to the abandonment of the former integrated management of cropland with extensive cattle-raising in upland pastures and woods. The agro-ecological complementarities among different land usages, that had created the traditional agro-forest mosaics, were suddenly ended. The mosaics themselves started to disappear with the rural society that had kept them alive. ${ }^{20}$

Taking advantage of the easy connections by railway and highway to Barcelona, in the last quarter of the twentieth century many former second residences were turned into permanent homes occupied by commuters. First La Garriga and then Figaró-Montmany became new edge residential areas of the metropolitan region. At the same time the socio-ecological pathologies of rural abandonment started to show their face: wildfires -there was a dangerous one between La Garriga and Figaró-Montmany in 1994 - , the loss of many old springs and paths used by former woodcutters, shepherds and charcoal-makers, and the proliferation of wild boar (often crossed with fast-reproducing pigs) which increasingly became pests. ${ }^{21}$

\footnotetext{
20 The importance of integration in farmland management is very well explained in C.A. Edwards, R.R. Grove, C.J. Harwood and P. Colfer, 'The role of agroecology and integrated farming systems in agricultural sustainability', Agriculture, Ecosystems \& Environment 46 (1993): 99 - 121.

${ }^{21}$ The socio-ecological consequences of rural abandonment have been examined, among others, by J. McNeill, The Mountains of the Mediterranean World: An environmental history (Cambridge: Cambridge University Press, 1992); S.J. Pyne, Vestal fire: An environmental history, told through the fire, of Europe and Europe's encounter with the world (Seattle: University of Washington Press, 1997); D. MacDonald, J.R. Crabtree, G. Wiesinger, T. Dax, N. Stamou, P. Fleury, J. Gutierrez-Lazpita and A. Gibon, A., 'Agricultural abandonment in mountain areas of Europe: environmental consequences and policy response', Journal of Environmental Management 59 (2000): 47 - 69; and A.T. Grove, and 0. Rackham, The Nature of Mediterranean Europe: An ecological history (New Haven: Yale University Press, 2001). The recent unsustainable trends in the BMR are examined in E. Tello,
} 
LAND-USE CHANGES IN LA GARRIGA: FROM A POLY-CULTURAL MOSAIC TO A METROPOLITAN EDGE

We have three excellent sources that study landscape changes in La Garriga from the mid-nineteenth century to the present: 1) a cadastral land-use map at approximately 1:2,500 scale drawn up from fieldwork in 1853-1854, and kept in the Historical Municipal Archive of the township; 2) digital land-use maps created by GIS photo-interpretation and geo-referencing from overlapping aerial photographs taken in 1956 by the United States Army; and 3) a land cover digital map of 2005 created from satellite images. Beyond the unavoidable margins of error incorporated into any land mapping that explain small differences in acreage obtained with GIS metrics, or taken from the historical land-use statistics assessed without maps, the larger picture of land cover obtained from these digital maps are reliable. They are a fundamental basis for any landscape analysis from a historical perspective, as well as the only sources available to perform a GIS cover intersection analysis in order to obtain matrices of land-use changes experienced between two dates in a given territory. ${ }^{22}$

\footnotetext{
'Changing course? Principles and tools for local sustainability', in T. Marshall (ed), Transforming Barcelona (London: Routledge, 2004), 110 - 225.. See also other Catalan case studies near of ours in M. Boada, El Montseny: cinquanta anys d'evolució dels paisatges (Barcelona: Publicacions de l'Abadia de Montserrat, 2002); A. Badia; I. Otero, R. Maneja, M. Boada, G. Estany, 'Canvi global i paisatge a la Costa del Tet-Mont-rodon (Matadepera, Vallès Occidental): analitzar el passat per planificar el futur (1956-2006)', Documents d'Anàlisi Geográfica 52 (2008):31 - 48; G. Estany, A. Badia, M. Boada, I. Otero, 'Integració de fonts d'informació en l'anàlisi socioecològica dels canvis en el paisatge a Matadepera (Vallès Occidental) entre 1931 i 2007', Treballs de la Societat Catalana de Geografia, 65 (2008):44 - 54; and I. Otero, M. Boada, A. Badia, E. Plac, J. Vayreda, S. Sabaté, C.A. Gracia and J. Peñuelas, 'Loss of water availability and stream biodiversity under land abandonment and climate change in a Mediterranean catchment (Olzinelles, NE Spain)', Land Use Policy 28 (2011):207 - 218. 22 The making of these historical cadastral maps in Catalonia has been studied and inventoried by $\mathrm{F}$, Nadal, L. Urteaga and J.I. Muro, El Territori dels geòmetres. The cadastral map of 1854 has been processed with GIS software by Natàlia Valldeperas and Anna Ollés with the funds provided by the Batista i Roca Grant 2010PBR00002. The digital land cover maps of 1956 and 2005 have been provided by the Centre of Forest Ecology Research and Applications (CREAF) at the Autonomous University of Barcelona (http://www.creaf.uab.es/eng/index.htm). To make them comparable, the different categories of land uses adopted in each map have been homogenized in a single common legend following criteria consistent with the subsequent application of landscape ecology metrics (as will be explained in greater detail in a forthcoming article by J. Marull, E. Tello, P. Warde, F. Coll, $\mathrm{N}$. Valldeperas and A. Ollés, 'Recovering the history behind the ecological connectivity between two
} 
Unlike the typical distribution provided by other land-use statistics, these matrices not only allow us to know the land cover profiles of the same place at two different points in time. They also let us discover the historical dynamics behind any given land-use changes, as the former land usages that lie behind every type of land cover become apparent. Besides showing which land cover types have increased or decreased from a specific historical period to the next, a matrix of land-use changes reveals how shrinking land cover types were transformed, and from which older types of cover new ones were created. This allows the true complexity of land use change to emerge with unusual exactitude, rather than just relying on descriptions of general trends. Notice that along the second and third rows (marked in grey) of the two following matrixes shown in Table 4, you have all values (in percentage or acreage) of the prevailing land-uses in the former period (1856 in the first matrix or 1956 in the second). Then, in the last two columns on the right side you have the same information for the following time cut (1956 in the first matrix or 2005 in the second). The other cells show the surfaces that changed from the land use described on top of their own column, which corresponds to the start date, to the new land use that appears on the left of their own row corresponding to the end date. Therefore, as in any other matrix, these flows of land-use change are added up from the latter date along the rows, while they are accounted from the former date along the columns. The surfaces that remained unchanged appear in the diagonal (also marked in grey in Table 4).

natural protected sites and a metropolitan edge: The Congost Valley in Catalonia, 1850-2005'). The matrices of land-use change have been calculated using these homogenized land-use categories. 
TABLE 4. Matrix of the main land-use changes from 1856 to 1956 and 2005 in La Garriga

\begin{tabular}{|c|c|c|c|c|c|c|c|c|c|c|}
\hline & $\begin{array}{r}1 \\
\text { woods }\end{array}$ & $\begin{array}{r}2 \\
\text { scrubs }\end{array}$ & $\begin{array}{r}3 \\
\text { pasture }\end{array}$ & $\begin{array}{r}4 \\
\text { grains }\end{array}$ & $\begin{array}{r}5 \\
\text { vines }\end{array}$ & $\begin{array}{r}6 \\
\text { olive \& }\end{array}$ & $\begin{array}{r}7 \\
\text { Irriga- } \\
\text { ted }\end{array}$ & $\begin{array}{r}8 \\
\text { built-up }\end{array}$ & $\begin{array}{r}9 \\
\text { infra. }\end{array}$ & $\begin{array}{r}\text { hectares } \\
1956 \downarrow\end{array}$ \\
\hline$\% 1856 \rightarrow$ & $30.0 \%$ & $3.6 \%$ & $19.5 \%$ & $4.7 \%$ & $\begin{array}{r}26.6 \\
\%\end{array}$ & $3.0 \%$ & $11.8 \%$ & $0.6 \%$ & $0.3 \%$ & $100.0 \%$ \\
\hline hectares $1856 \rightarrow$ & 564.1 & 66.8 & 367.3 & 87.7 & 499.9 & 55.6 & 221.6 & 10.6 & 6.3 & $1,879.7$ \\
\hline 1. woodland & 398.6 & 11.4 & 203.1 & 9.2 & 253.0 & 8.7 & 6.7 & 0.6 & 0.9 & 892.2 \\
\hline 2. scrubland & 12.8 & 20.1 & 15.0 & 1.5 & 17.9 & 0.7 & 8.1 & 0.3 & 0.2 & 76.6 \\
\hline 3. pastureland & 0.2 & 0.0 & 2.1 & 0.2 & 3.9 & 0.9 & 0.0 & 0.0 & 0.0 & 7.3 \\
\hline 4. rain-fed grains & 57.6 & 7.4 & 81.8 & 35.9 & 115.4 & 10.5 & 30.0 & 1.2 & 2.1 & 341.9 \\
\hline 5. vineyards & 11.2 & 0.3 & 13.1 & 2.7 & 14.1 & 3.7 & 1.2 & 0.0 & 0.0 & 46.3 \\
\hline 6. olive \& other trees & 52.1 & 2.8 & 28.5 & 15.3 & 72.0 & 24.1 & 21.0 & 0.6 & 0.5 & 216.9 \\
\hline 7. irrigated orchards & 27.1 & 17.9 & 18.7 & 17.1 & 8.0 & 2.8 & 93.9 & 0.7 & 0.7 & 186.9 \\
\hline 8. built-up area & 2.2 & 5.6 & 3.1 & 3.8 & 11.3 & 3.1 & 54.0 & 6.9 & 1.6 & 91.6 \\
\hline 9. infrastructure & 2.3 & 1.3 & 1.9 & 2.0 & 4.3 & 1.1 & 6.7 & 0.3 & 0.3 & 20.2 \\
\hline \multicolumn{10}{|c|}{ Area with no land-use change from 1856 to 1956} & 596.0 \\
\hline \multirow[t]{2}{*}{ id. land-use changes } & 165.5 & 46.7 & 365.2 & 51.8 & 485.8 & 31.5 & 127.7 & 3.6 & 6.0 & $1,283.6$ \\
\hline & woods & scrubs & pasture & grains & vines & olive \& & $\begin{array}{r}\text { Irri- } \\
\text { gated }\end{array}$ & built-up & infra. & $2005 \downarrow$ \\
\hline$\% 1956 \rightarrow$ & $47.5 \%$ & $4.1 \%$ & $0.4 \%$ & $\begin{array}{r}18.2 \\
\%\end{array}$ & $2.5 \%$ & $11.5 \%$ & $9.9 \%$ & $4.9 \%$ & $1.1 \%$ & $100.0 \%$ \\
\hline hectares $1956 \rightarrow$ & 892.2 & 76.7 & 7.3 & 341.8 & 46.3 & 216.9 & 186.9 & 91.5 & 20.3 & $1,879.7$ \\
\hline 1. woodland & 843.2 & 40.8 & 1.1 & 109.2 & 7.4 & 42.5 & 8.7 & 1.2 & 0.4 & $1,054.5$ \\
\hline 2. scrubland & 23.6 & 13.3 & 1.1 & 39.1 & 5.2 & 13.5 & 5.5 & 1.1 & 0.2 & 102.6 \\
\hline 3. pastureland & 2.7 & 6.1 & 0.0 & 11.1 & 1.3 & 4.1 & 5.7 & 0.9 & 0.1 & 32.0 \\
\hline 4. rain-fed grains & 3.1 & 1.5 & 0.1 & 70.9 & 8.6 & 51.6 & 40.2 & 0.3 & 0.1 & 176.4 \\
\hline 5. vineyards & 0.4 & 0.0 & 0.6 & 6.1 & 3.5 & 1.0 & 0.0 & 0.0 & 0.0 & 11.6 \\
\hline 6. olive \& other trees & 1.0 & 0.4 & 0.0 & 27.1 & 6.6 & 50.2 & 2.7 & 0.1 & 0.0 & 88.1 \\
\hline 7. irrigated orchards & 0.0 & 0.2 & 0.0 & 0.4 & 0.0 & 0.1 & 5.9 & 1.0 & 0.3 & 7.9 \\
\hline 8. built-up area & 15.2 & 14.3 & 4.2 & 72.3 & 13.1 & 52.8 & 116.7 & 86.9 & 2.3 & 377.8 \\
\hline 9. infrastructure & 3.0 & 0.1 & 0.2 & 5.6 & 0.6 & 1.1 & 1.5 & 0.0 & 16.9 & 29.0 \\
\hline \multicolumn{10}{|c|}{ Area with no land-use change from 1956 to 2005} & $1,090.8$ \\
\hline id. land-use changes & 49.0 & 63.4 & 7.3 & 270.9 & 42.8 & 166.7 & 181.0 & 4.6 & 3.4 & 788.8 \\
\hline hectares $2005 \rightarrow$ & $1,054.5$ & 102.6 & 32.0 & 176.4 & 11.6 & 88.1 & 7.9 & 377.8 & 29.0 & $1,879.7$ \\
\hline$\% 2005 \rightarrow$ & $56.1 \%$ & $5.5 \%$ & $1.7 \%$ & $9.4 \%$ & $0.6 \%$ & $4.7 \%$ & $0.4 \%$ & $20.1 \%$ & $1.5 \%$ & $100.0 \%$ \\
\hline
\end{tabular}

Sources: 
Calculated by Natàlia Valldeperas and Anna Ollés with GIS software out of the digital maps of land-use and land covers of La Garriga township in 1854, 1956 and 2005.

If we examine the extent of the land cover reallocations experienced in La Garriga, by adding up all the hectares recorded in the diagonal of the two matrices shown in Table 4, we can see that from 1856 to 1956 only 32 per cent of land covers remained unchanged; 58 per cent from 1956 to 2005; and for the whole period from 1854 to 2005 the corresponding figure is 26 per cent. Even if the land-use changes registered are potentially exaggerated a little due to unavoidable mismatches in the land cover intersection with GIS from the cumulative effects of small errors in geo-referring the perimeters of all landscape units from the original cadastral maps, the numbers presented here are nevertheless still so large that we can perceive the real existence of a major turnover in the landscape during a century and a half. Change was registered in 68 per cent of the territory from 1856-1956, 42 per cent from 1956-2005, and 74 per cent from 1856 to 2005. Another interesting point revealed by these matrices is that land-use changes seem have to be much less unidirectional than expected: reallocations appear in both directions across land uses for almost all possible categories, even where there is a net outcome with a clear direction. ${ }^{23}$

As seen in Figure 4, the starting point in 1856 was the cultural landscape created by an intensive organic and polycultural agricultural system, combining a significant amount of irrigated orchards on 11.8 per cent of the territory along the Congost River, with a mosaic made out of rain-fed cereals (4.7 per cent), vineyards (26.6 per cent), other tree crops such as olive orchards, almonds or hazelnuts (3 per cent), and pastures (19.5 per cent) that spread over the flattest parts of twothirds of the municipal area. An interesting feature of this case study is that pasturelands were tightly interwoven with arable land, instead of being found with

${ }^{23}$ Using GIS techniques in historical studies is still a novel area of work, so there are few examples with which to compare these data. In the case of Tuscany, Mauro Agnoletti has found $60 \%$ of land cover changes from 1832 to 1954 and 29\% from 1954 to 2004 in a sample of thirteen study areas rather similar values to our figures after considering the marginal errors that all of them may contain (our own calculation, from the land-use matrices published in 'The Development of Historical and Cultural Evaluation Approach in Landscape Assessment: the Dynamic of Tuscan Landscape between 1832 and 2004', in The Conservation of Cultural Landscapes, 16 and 19).. 
woods and scrubs as seems more usual in the Vallès County or other Catalan regions. This suggests that these pasturelands were seasonally leased in exchange for manure, either to cattle coming from Figaró-Montmany or to transhumant sheep coming from the Pyrenees, a common practice that would help to fill the fertilizer gap. This patchwork mosaic was extended up to the woodlands (30 per cent) and scrubs (3.6 per cent) covering the other third of the land. Again it is worth noting that these forestlands not only overlaid the steepest hillsides in the Northern and Western borders of the township, but the Southern and Eastern plains as well (Figure 3). ${ }^{24}$

${ }^{24}$ Land-use patterns and dynamics in other parts of the province of Barcelona can be seen in E. Tello, R. Garrabou and X. Cussó, 'Energy Balance and Land Use'; R.Garrabou, E. Tello and X. Cussó, 'El cambio de usos del suelo en la comarca del Vallès (1850-2000): fuerzas motoras y agentes rectores de la transformación del territorio', in R. Garrabou and Naredo, J.M. (eds), El paisaje en perspectiva histórica. Formación y transformación del paisaje en el mundo mediterráneo (Zaragoza: SEHA/Prensas Universitarias de Zaragoza, 2008), 233 - 258; and Ll. Parcerisas, J. Marull, J. Pino, E. Tello, F. Coll and C. Basnou, 'Land use changes, landscape ecology and their socioeconomic driving forces in the Spanish Mediterranean coast (El Maresme County, 1850-2005)', Environmental Science \& Policy 23 (2012): $123-132$. 
FIGURE 3. Land-uses and land cover types in La Garriga:

According to the cadastral map of 1856

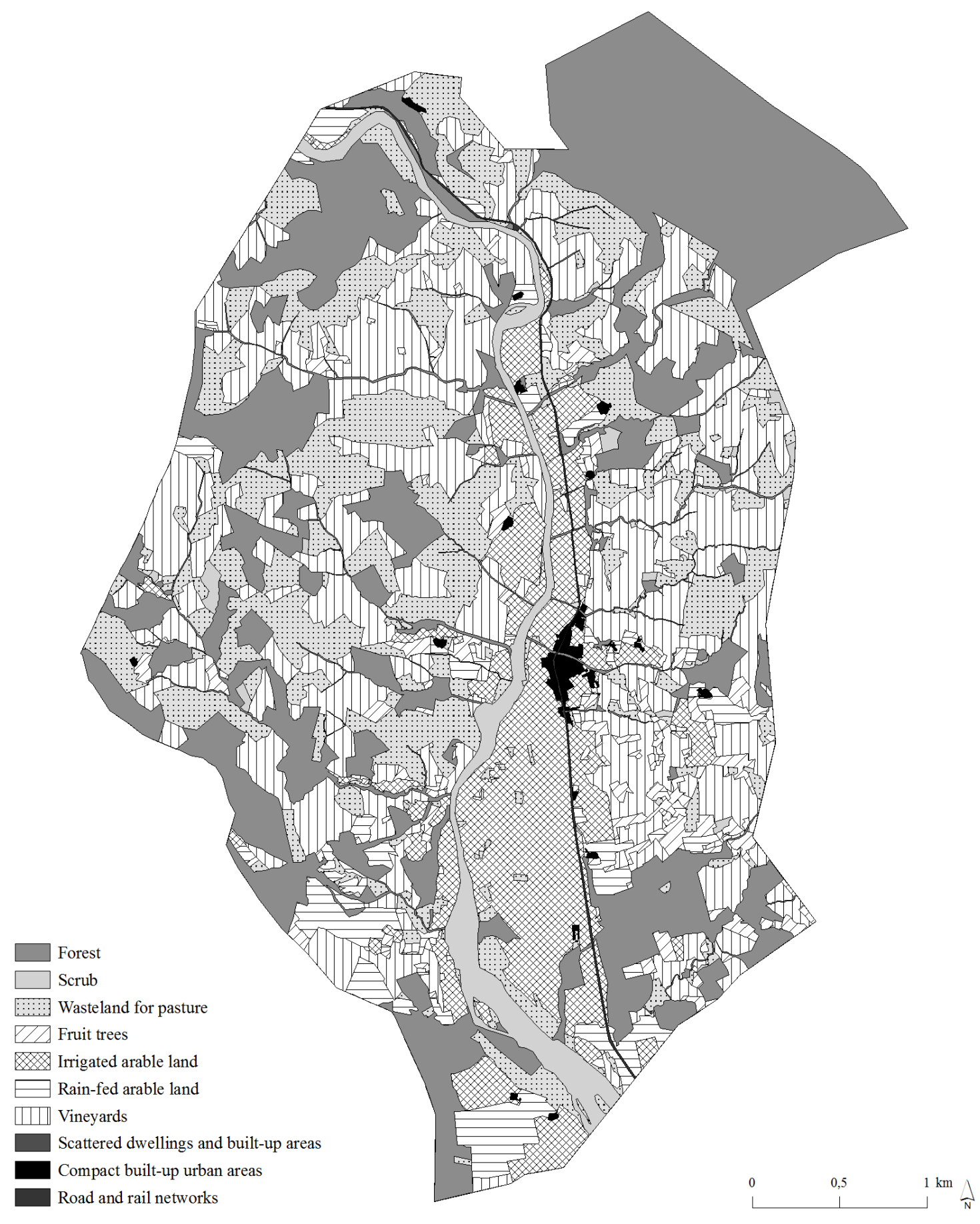


According to the aerial photographs of 1956

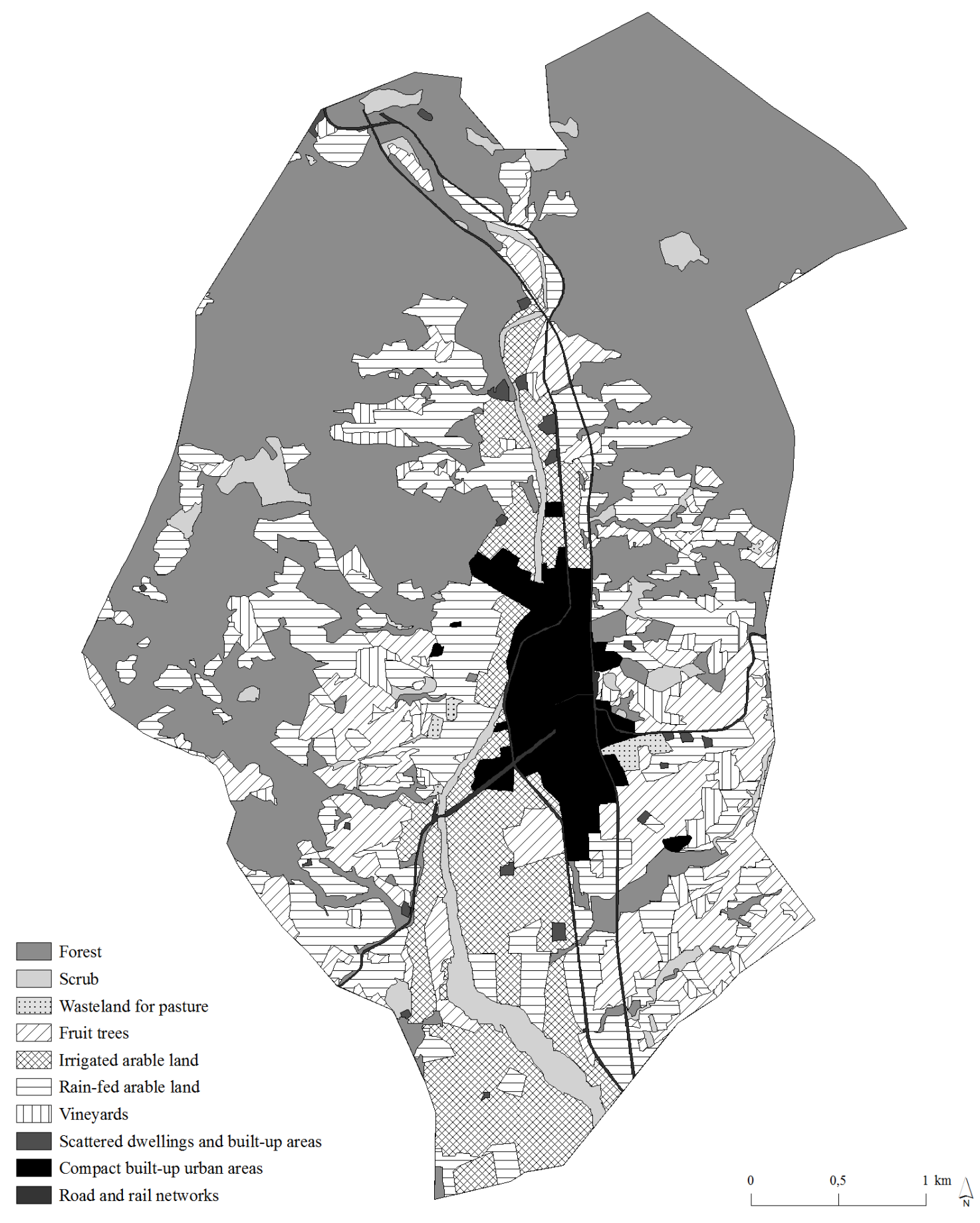




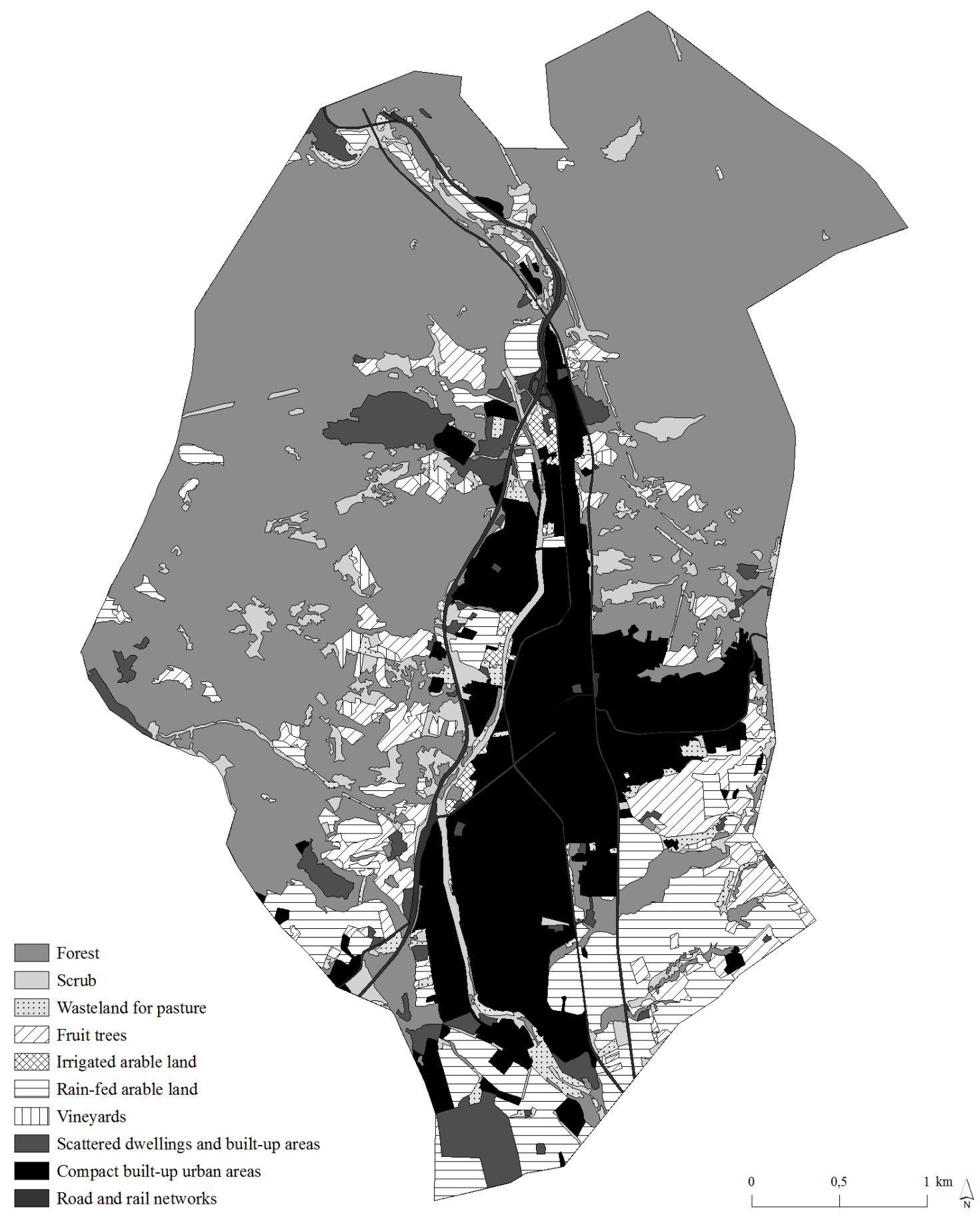

Sources:

Drawn at the IERMB out of the GIS digital layers obtained by Natalia Valldeperas from the cadastral map of 1854 kept in the Historical Municipal Archive of La Garriga, from the geo-interpretation of the aerial photographs 
taken 1956 by the United States Army provided by the CREAF and from the GIS digital layers obtained from satellite images.

From 1854 to 1956 the total amount of cultivated land (46 per cent in the former and 42 per cent in the latter) or land covered by wood, scrub and pasture (53 per cent and 52 per cent respectively) did not register highly significant changes. There were however other important rearrangements within each of these landuse categories that transformed the overall cultural landscape. First of all, during the 1880s all vines were killed by the Phylloxera Vastatrix plague, and only a small fraction of the former vineyards were replanted in La Garriga with resistant strains coming from America. In 1956 the new vines only occupied 2.5 per cent of the municipal area, and 55 per cent of the vineyards existing in 1856 had been turned into forests, scrub or wasteland (-275 ha), 23 per cent into rain-fed arable land sown with grains (-115 ha), 14 per cent into different tree crops (-72 ha), and the rest (-7 ha) became irrigated gardens or built-up areas. The abandonment of vinegrowing was the first important land-use change from mid-nineteenth to midtwentieth century in this township. ${ }^{25}$

A second deep change happened inside the uncultivated lands, with a significant decrease in pasturelands (-360 ha) that mainly became spontaneously reforested. Woodlands and scrubs also increased significantly (+338 ha) although the fluxes of land-use reallocations were more complicated than simply changing pasture areas into forests, as shown in the matrices of Table 4. Behind the practical disappearance of pastureland lay the collapse of the extensive, organic grazing of herds, replaced with new industrial feed-lots where livestock was fed with imported grains. Pasturelands were invaded by new forests and brushwood, mainly in the Northern and Western sides of the municipality. The joint abandonment of extensive grazing and vine-growing entailed a reduction in the complexity of landscape mosaics, where all sorts of cropland had been interwoven. Those two trends were combined with a noticeable increase of built-

\footnotetext{
${ }^{25}$ For the regional impact of this plague see M. Badia-Miró, E. Tello, F. Valls and R.Garrabou, 'The Grape Phylloxera Plague as a Natural Experiment: The Upkeep of Vineyards in Catalonia (Spain, 1858-1935)', Australian Economic History Review 50 (2010): 39 - 61.
} 
up land and areas devoted to infrastructure facilities, both in absolute numbers (+95 ha, jumping from only 17 ha in 1856 to 112 ha in 1956) and in relative terms - a nearly seven fold increase. Nevertheless, as seen in Map 3, the agricultural mosaic remained in place over a significant share of the township together with the irrigated gardens near the river, which in 1956 had lost -35 ha out of the 222 ha existing in 1856.

The biggest landscape turnaround occurred between 1956 and 2005. What stands out most when comparing the second and third maps in Figure 3 is the explosion of built-up areas, whether urban land or infrastructural facilities. During this period +303 ha was paved, or covered with concrete and asphalt: 16 per cent of the whole municipal area and 38 per cent of all land cover changes undertaken in this territory during this period. It is also striking that most of this has probably led to irreversible soil degradation on the most fertile irrigated lands of the township. This draws attention towards the particular dynamics of another type of edge, the one linking built-up land with the countryside. Following the marketdriven logic pointed out by Von Thünen, the village border created around it a ring of irrigated orchards where fresh fruits were grown. A question was going to be posed when the village border needed to be extended due to population and economic growth: should new land developments be extended over the market gardening zone or should that be preserved by building on a more distant location?

Once the riparian vegetation along both sides of the river, long ago transformed into orchards, was built over it could never be reproduced elsewhere. The choice of building over the gardening zone of a village like La Garriga gave no option of return. This is not an extemporaneous question: it was already raised in Catalonia in the early twentieth century by Cebrià de Montoliu (1873-1923) and other land-use planners who advocated garden-city movement ideas leading to the Regional Planning of Catalonia Act passed in 1932. The failure of these alternative approaches epitomises the lack of an adequate land-use zoning and regional planning in Catalonia both during the long dictatorship of General Franco, and after. $^{26}$

\footnotetext{
${ }^{26}$ The Catalan city-garden movement during the 1920s and 1930s, and its connections with the anarchism, are explained in J. Martínez Alier, 'Urban sprawl and ecology in Barcelona', and E. Masjuan, La ecología humana en el anarquismo ibérico. We present other apparent examples of the
} 
The second biggest land cover change during the last fifty years is spontaneous reforestation following rural abandonment. Together with urban expansion this means that the traditional agro-forest mosaics only survive in La Garriga as relicts mainly located in the South-East side of the township - perhaps because a small water reservoir allows the irrigation of the area. People owning these remaining fields face the dilemma of whether to continue as peri-urban farmers or take offers from urban land developers to give up their land. As always, decisions will be shaped by public policy and the implementation of regional planning. 27

The cultural landscapes of La Garriga experienced a deep socio-ecological transition from a poly-cultural mosaic of 1854, created by highly intensive organic agriculture in a mainly rural but already industrializing village, to a residential town located in 2005 inside the farthest edge of the BMR - now placed face to face with the Montseny Natural Park and the protected site of the Cingles de Bertí. In 1956 its landscape was still a combination of agro-forest mosaics with a growing residential town and a blooming resort area joined to a small industrial cluster of textile manufacturers and furniture makers. Now the future of this community placed in such an edge environment will depend again on how Catalan and European society decides to value environmental services and care for the ecological functioning of the land matrix on which they live.

\footnotetext{
Spanish lack of regional planning in Ll. Parcerisas et al., 'Land use changes, landscape ecology and their socioeconomic driving forces in the Spanish Mediterranean coast'.

${ }^{27}$ These trends are local expressions of the global ones examined, for example, in E. Lambin, M.D.A. Rounsevell and H.J. Geist, 'Are agricultural land-use models able to predict changes in land-use intensity?', Agriculture, Ecosystems and Environment 82 (2000): 321 - 331; C. Stoate, N.D. Boatman, R.J. Borralho, C. Rio Carvalho, G.R de Snoo and P. Eden, 'Ecological impacts of arable intensification in Europe', Journal of Environmental Management 63 (2001): 337 - 365; and T.K. Rudel, 0.T. Coomes, E. Moran, F. Achard, A. Angelsen, J. Xu and E. Lambin, 'Forest transitions: towards a global understanding of land use change', Global Environmental Change 15 (2005): 23 - 31. These trends are also studied in the BMR by B. Catalán, D. Saurí and P. Serra, 'Urban Sprawl in the Mediterranean? Patterns of growth and change in the Barcelona Metropolitan Region 1993-2000', Landscape and Urban Planning 85 (2008): 174 - 184; and J. Marull et al., 'Social metabolism, landscape change and land-use planning in the Barcelona Metropolitan Region'.
} 


\section{CHANGE BENEATH APPARENT PERMANENCE: FIGARÓ-MONTMANY}

The most prominent feature of the landscape evolution of Figaro-Montmany seems at first to be permanence - exactly the opposite of La Garriga. However, we must take a critical distance from this image of immobility. The overall picture of the land-use pattern in this mountain township is blurred by the ambiguities and shifting criteria of assessment of what was considered pasture, wasteland, scrub or woodland. There were two different aspects behind these problems in categorization. When relying on written sources and maps, historians have to deal with the information that ruling elites drew up about rural society. They always found it more difficult to get information on large and inaccessible forestlands and pastures, as well as the people living on them in scattered settlements, compared with the denser agricultural townships located in the plains. ${ }^{28}$ The complexity and adaptability of the multipurpose uses of forests integrated with other uncultivated areas was also a great ally in local efforts to escape control and taxation. Thus, it was not only their ability to deceive tax collectors; the land-use categories which the surveyors wanted to assess in a fixed and separate way were always overlapping and shifting their boundaries in a manner incomprehensible to people lacking the local knowledge of the villagers who managed those lands. ${ }^{29}$

Looking at the available cadastral figures, the land devoted to woodland and pasture was always over 70 per cent during the nineteenth century and 90 per cent in the twentieth century. Vineyards were by far the main crop in the cultivated land during the former period, but were reduced to almost nothing after the Phylloxera Plague. Giving up winegrowing further strengthened the forest character of this township (Table 5).

\footnotetext{
28 The inaccuracies and ambiguous meanings of land-use statistics in mainly woodland mountain areas is stressed by A.T. Grove and 0. Rackham in The Nature of Mediterranean Europe. As explained in the text, the land-uses taken from the official statistics and maps compiled in a densely populated and intensively cultivated plain of La Garriga become much more trustworthy than the same obtained in the mountains of Figaró-Montmany, mainly covered with a complex interwoven pattern of woodlands and pasturelands managed by a low, scattered and rebel population (see also footnote 33).

29 For a general perspective, see M.A. Altieri, 'Agroecology: the science of natural resource management for poor farmers in marginal environments', Agriculture, Ecosystems and Environment 93 (2002): 1 - 24. For a Catalan case study of a mountain village made combining written and oral sources, see I. Otero and M. Boada, El patrimony socioecològic de la pagesia. L'exemple d'Olzinelles, al massís del Montnegre (Barcelona: Publicacions de l'Abadia de Montserat, 2012).
} 
TABLE 5. Main land uses in Figaró-Montmany according to the available statistics (1858-1976)

\begin{tabular}{|c|c|c|c|c|c|c|c|c|}
\hline & \multicolumn{2}{|r|}{1858} & \multicolumn{2}{|r|}{1861} & \multicolumn{2}{|r|}{1941} & \multicolumn{2}{|r|}{1976} \\
\hline & $\mathrm{Ha}$ & $\%$ & ha & $\%$ & ha & $\%$ & ha & $\%$ \\
\hline & & & & & 2.3 & & & \\
\hline irrigated vegetables & & -- & -1 & -- & 5.2 & 0.1 & & -- \\
\hline irrigated fruit trees orchards & 284 & -- & 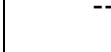 & -- & 13.0 & 0.3 & & -- \\
\hline irrigated cereal cropland & 284 & 1.8 & 27.9 & 2.3 & 20.4 & 0.9 & 44.0 & -- \\
\hline TOTAL IRRIGATED LAND & 1089 & 1.8 & 27.9 & 2.3 & 66.2 & 1.3 & 33.0 & 3.1 \\
\hline rain-fed cereal cropland & 1373 & 6.9 & 88.8 & 7.3 & 79.2 & 4.3 & -- & 2.3 \\
\hline TOTAL CEREAL CROPLAND & 2454 & 8.7 & 116.8 & 9.6 & 0.0 & 5.2 & -- & -- \\
\hline vineyards & & 15.5 & 196.9 & 16.2 & 13.2 & 0.0 & -- & -- \\
\hline olive groves & 3012 & 3.5 & 35.6 & 2.9 & 13.2 & 0.9 & 13.0 & -- \\
\hline TOTAL TREE CROPS & 438.5 & 19.0 & 232.4 & 19.2 & 99.8 & 0.9 & 90.0 & 0.9 \\
\hline TOTAL CROPLAND AREA & 182.3 & 27.7 & 349.2 & 28.8 & 435.3 & 6.6 & $\begin{array}{r}1,078 . \\
0\end{array}$ & 6.4 \\
\hline Timberland/ pine woodland & 371.1 & 11.5 & 180.3 & 14.9 & 453.4 & 28.6 & -- & 76.4 \\
\hline Firewood/ holm oak woodland ${ }^{* *}$ & & 23.4 & 357.6 & 29.5 & 208.4 & 29.8 & -- & -- \\
\hline Scrubland $^{* * *}$ & 553.4 & -- & & -- & 1,097 . & 13.7 & 1078 & -- \\
\hline TOTAL WOODLAND AREA & 5919 & 34.9 & 537.9 & 44.3 & & 72.0 & 0 & 76.4 \\
\hline PASTURELAND $^{* * * *}$ & 1145 & 37.4 & 26.4 & 26.9 & 26.9 & 21.5 & 243.0 & 17.2 \\
\hline TOTAL WOODS AND PASTURE & & 72.3 & 864.3 & 71.2 & 1,424 & 93.4 & $1,321$. & 93.6 \\
\hline TOTAL UAA ${ }^{* * * * *}$ & $\begin{array}{r}1,583 . \\
8\end{array}$ & 100.0 & $\begin{array}{r}1,213 \\
5\end{array}$ & 100.0 & $\begin{array}{r}1,523 . \\
9\end{array}$ & 100.0 & $\begin{array}{r}0 \\
1,411 . \\
0\end{array}$ & 100.0 \\
\hline
\end{tabular}

Notes:

* 'Timberland' ('bosque de construcción' in Spanish) is the name given by the statistics of 1858 and 1861, and again in 1976 ('monte maderable'), while the category 'pine woodlands' ('pinares') is used in 1941 for these areas.

** 'Firewood woodland' ('bosc de fagina' in Catalan) is the name given by the statistics of 1858 and 1861, and again in 1976 ('monte leñoso' in Spanish), while the category 'holm oak woodland' ('encinares') is used in 1941 for these areas.

*** The category 'scrubland' ('monte bajo' o 'matorral') only appears differentiated in 1941, in the rest of the years it must be mixed with holm oak woodland. 
**** We have included here the Spanish categories of 'yermo' and 'erial' (or 'erm' in Catalan, which literary means 'wasteland') that sometimes are also referred to as 'erial a pastos' ('wasteland devoted to pasture') in the sources.

***** 'Useful Agricultural Area'. The official total extent of the township is 1,580 hectares at present, and the differences in the total acreage recorded in the table come from the respective inaccuracies in land accounts. Rocky crags, water streams and built-up areas are not included in these figures (e.g. the Amillaramiento of 1861 included 157 ha of 'rocky lands').

Sources:

Taken by Enric Tello from the Land-Use Statistics in the Province of Barcelona in 1858, the cadastral Amillaramientos of 1861 and 1941, and the agricultural census of 1976 kept in the Historical Municipal Archive of Figaró-Montmany.

Unfortunately, the cadastral map of this township made in 1854 has been lost. We have however a very detailed map made in $1949 .{ }^{30}$ Although this reduces the possibilities for calculating a matrix of land-use changes to the second half of the twentieth century, it is enough to test the lesser land cover reallocation which took place in this municipality. While in La Garriga up to 42 per cent of the area changed land cover from 1956 to 2005, in Figaró-Montmany only 28 per cent did so from 1949 to 2005 (Table 6). In addition to the reduction experienced by all sorts of cropland, and the increase in built-up areas or land devoted to infrastructures, it is worth noting the contraction of the pastureland: from nearly 80 hectares in 1949 to less than 20 hectares in 2005.

\footnotetext{
${ }^{30}$ See F. Nadal et al., El Territori dels geòmetres. The year 1949 is a surprising date for such an expensive task. Possibly the old map of 1854 was simply copied and rectified according to the land uses recorded in the Amillaramiento of 1941, which would explain the lack of interest in keeping the former one in the archive. The 1949 map is kept by the City Council of Figaró-Montmany.
} 
TABLE 6. Matrix of the main land-use changes from 1949 to 2005 in FigaróMontmany

\begin{tabular}{|c|c|c|c|c|c|c|c|c|c|c|}
\hline & $\begin{array}{r}1 \\
\text { woods }\end{array}$ & $\begin{array}{r}2 \\
\text { scrubs }\end{array}$ & $\begin{array}{r}3 \\
\text { pasture }\end{array}$ & $\begin{array}{r} \\
\text { grains } \\
\end{array}$ & $\begin{array}{r}5 \\
\text { vines }\end{array}$ & $\begin{array}{r}6 \\
\text { olive \& }\end{array}$ & $\begin{array}{r}7 \\
\text { irrigated }\end{array}$ & \begin{tabular}{|r|}
8 \\
built-up
\end{tabular} & $\begin{array}{r}9 \\
\text { infra. }\end{array}$ & $\begin{array}{r}\text { hectares } \\
2005 \downarrow\end{array}$ \\
\hline$\% 1949 \rightarrow$ & 81.2 & 0.0 & 5.3 & 4.9 & 0.5 & 2.4 & 3.0 & 0.8 & 1.8 & 100.0 \\
\hline hectares $1949 \rightarrow$ & $1,216.4$ & 0.0 & 79.9 & 73.7 & 7.7 & 35.5 & 45.4 & 12.1 & 27.4 & $1,498.1$ \\
\hline 1. woodland & $1,041.7$ & 0.0 & 61.8 & 29.2 & 2.9 & 22.1 & 17.9 & 1.8 & 18.6 & $1,196.0$ \\
\hline 2. scrubland* & 136.2 & 0.0 & 10.6 & 7.5 & 2.0 & 8.8 & 3.0 & 0.6 & 2.9 & 171.6 \\
\hline 3. pastureland & 10.9 & 0.0 & 5.0 & 2.0 & 0.1 & 0.3 & 0.9 & 0.2 & 0.3 & 19.7 \\
\hline 4. rain-fed grains & 9.5 & 0.0 & 0.3 & 25.5 & 1.9 & 0.2 & 1.6 & 0.3 & 0.6 & 39.8 \\
\hline 5. vineyards & 0.0 & 0.0 & 0.0 & 0.0 & 0.0 & 0.0 & 0.0 & 0.0 & 0.0 & 0.0 \\
\hline 6. olive \& other trees & 0.4 & 0.0 & 0.0 & 0.5 & 0.1 & 0.0 & 0.0 & 0.0 & 0.0 & 1.1 \\
\hline $\begin{array}{ll}7 . & \text { irrigated } \\
\text { orchards } & \end{array}$ & 0.0 & 0.0 & 0.0 & 0.0 & 0.0 & 0.2 & 0.3 & 0.0 & 0.0 & 0.5 \\
\hline 8. built-up area & 13.7 & 0.0 & 2.0 & 8.9 & 0.5 & 3.6 & 19.3 & 8.5 & 4.1 & 60.5 \\
\hline 9. infrastructure ${ }^{* * *}$ & 4.0 & 0.0 & 0.2 & 0.2 & 0.1 & 0.4 & 2.3 & 0.6 & 0.9 & 8.8 \\
\hline \multicolumn{10}{|c|}{ Area with no land-use change from 1949 to $2005^{* * * *}$} & $1,082.0$ \\
\hline id. land-use changes & 174.7 & 0.0 & 74.9 & 48.2 & 7.7 & 35.5 & 45.1 & 3.5 & 26.5 & 416.1 \\
\hline hectares $2005 \rightarrow$ & $1,196.0$ & 171.6 & 19.7 & 39.9 & 0.0 & 1.1 & 0.5 & 60.5 & 8.8 & $1,498.1$ \\
\hline$\% 2005 \rightarrow$ & 79.8 & 11.5 & 1.3 & 2.7 & 0.0 & 0.1 & 0.0 & 4.0 & 0.6 & 100.0 \\
\hline
\end{tabular}

Notes:

* The land cover map of 1949 does not include scrubland. Due to its strong forestry bias, it is likely that areas covered by shrubs and thickets were considered potential woodlands.

** This land-use category includes in the land cover map of 1949 a small proportion of flood plains along the Congost river, and its tributary creeks, which in some places were used to plant and grow alders, poplars and planes.

*** This land-use category includes in the land cover map of 1949 some amount of 'unproductive areas'.

**** As explained in the text, there are some differences in acreage between this GIS metrics applied to the available land cover maps, and the figures given in Table 6 were taken from land-use historical statistics. They come from the unavoidable margins of error of these land accounts and the diverse criteria used in land-use categories by the original maps. 
Sources:

Calculated by Natàlia Valldeperas and Anna Ollés with GIS software out of the digital maps of land-use and land covers of Figaró-Montmany township in 1949 and 2005.

Combining Tables 2, 5 and 6 with Figure 2 we can see that from the midnineteenth to the mid-twentieth century arable land shrunk from some 28 per cent to between 7 or 10 per cent of the territory, and to less than 3 per cent in 2005 . It is also notable that the population almost halved from 695 inhabitants in 1860 to only 379 in 1887 - just when the Phylloxera Plague had ravaged all vines. Then, mainly due to the economic impact of incoming vacationers, the local population increased slowly to 463 in 1930, 519 in 1940, and 571 in 1960. Under the influence of urban sprawl inside the MBR, population increased again to 624 in 1991 and 1,057 in 2009. As throughout this period around 80 per cent of the land was woodland, and between 8 per cent to 13 per cent scrubs or reforesting lands, it becomes important to disentangle the different non-agricultural land usages.

To recover some real changes underlying the seeming immobility, we can examine not only the land cover types but also the values of taxable net incomes recorded in the cadastres. Figure 4 shows a transition from a mixed agro-forestrypastoral village economy in 1861, when most taxes were raised from farming (65 per cent), towards specialization in forestry that by 1941 provided the majority of taxable income (62 per cent) from lumbering and charcoal making. It is likely that mid-nineteenth century non-agricultural incomes were overestimated due the inability of tax collectors to assess livestock breeding and forestry activities. Nevertheless, the shift is too large not to reflect a real transition towards a mainly forestry economy. This also fits very well with recent historical studies which have stressed that during industrialization and urbanization wood and firewood 
consumption continued to grow, adding to the increase in fossil fuels consumed instead of being replaced by them. ${ }^{31}$

FIGURE 4. Distribution of cadastral taxable net incomes among rural activities of Figaró-Montmany (in 1861 and 1941)

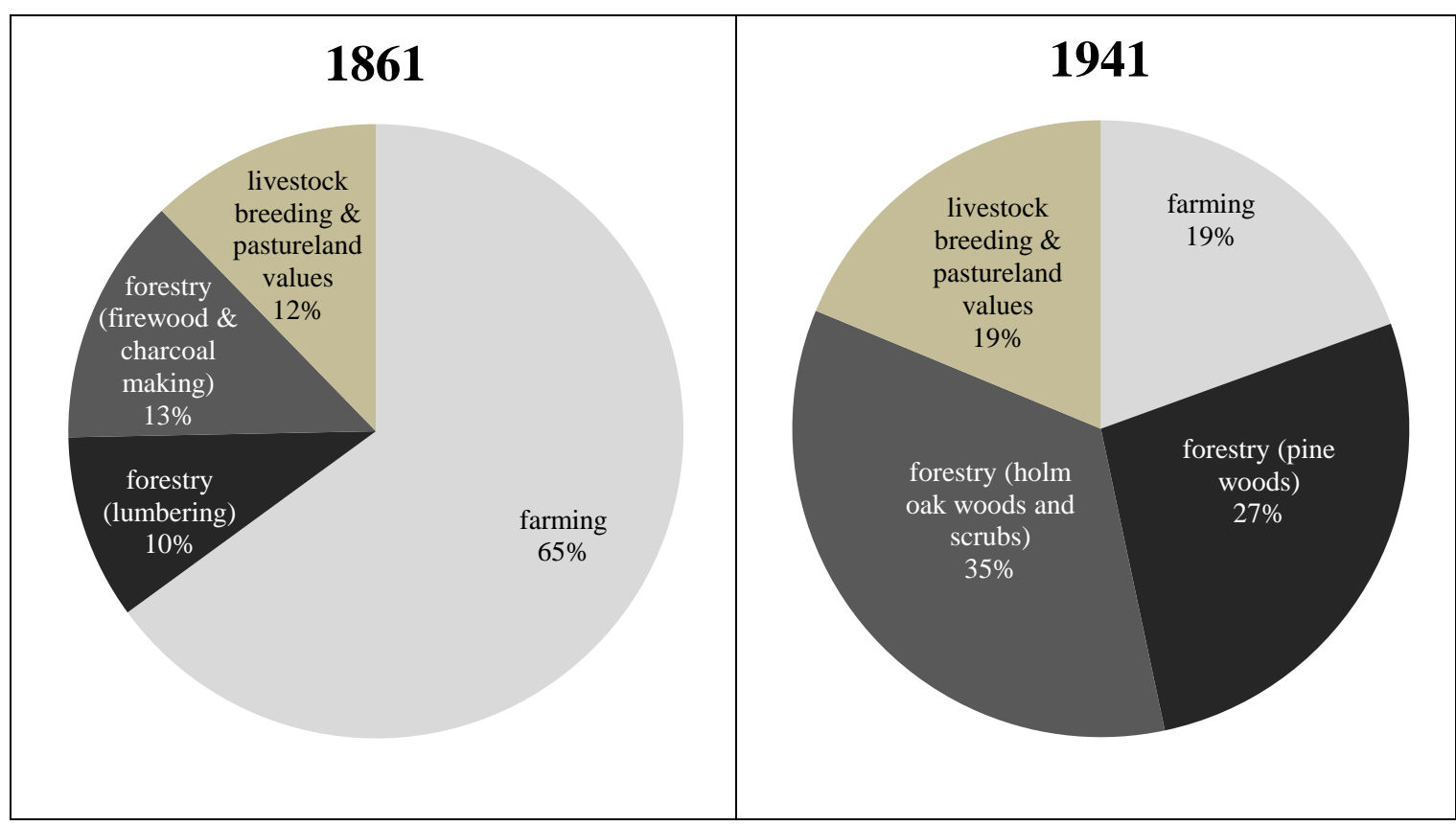

Sources:

Taken by Enric Tello from the cadastral Amillaramientos of 1861 and 1941 kept in the Historical Municipal Archive of Figaró-Montmany.

The ongoing urbanization and economic growth in Barcelona and the Vallès plain undoubtedly entailed rising domestic fuel consumption, which was mainly provided by charcoal-makers such as those working in the holm and oak woods of Figaró-Montmany. It is even likely that charcoal-making reached its peak during the first half of the twentieth century, just before the arrival of butane gas

${ }^{31}$ I. Iriarte-Goñi and M.I. Ayuda, 'Not only subterranean forests: Wood consumption and economic development in Britain (1850-1938)', Ecological Economics 77 (2012):176 - 184; and for the case of Spain, I. Iriarte-Goñi, 'Forests, Fuelwood, Pulpwood, and Lumber in Spain, 1860-2000: A Nondeclensionist story', Environmental History 18 (2013):333-359. 
cylinders during the early 1960s. In 1941 firewood collection and pruning of oak branches to be burnt in charcoal-kilns still provided 35 per cent of net incomes of Figaró-Montmany, while lumbering and sawing pine planks generated another 27 per cent, supplying the furniture industry in the neighbouring townships of La Garriga and L'Ametlla del Vallès.

Looking at Tables 5 and 6 we can assume an overall stability in the land devoted to pasture -some of which was probably included under the category of abandoned or denuded lands in the 1949-2005 matrix of changes - or perhaps a slight decline. However it is very difficult to make any definitive statement on that issue due to elusive criteria about what was considered as woodland, scrubland or pasture in each cadastral source or map. Another clue is the relative increase in net income attributed by tax sources to livestock breeding, as shown in Figure 4. This also fits with the impression given by the livestock numbers appearing in the census: they diminished only a little and changed composition when the local economy became more specialized in forestry after the abandonment of vinegrowing from the mid-nineteenth century to the first half of the twentieth century. Then extensive livestock grazing suddenly collapsed during the 1960s, more or less at the same time as charcoal-making was abandoned. This retreat from traditional multiple-use of woodlands, scrubs and pastures entailed a deep caesura in the landscape leading to reforestation after abandonment. ${ }^{32}$

In order to understand the environmental impact of this event we need to go beyond the general categories and limitations of land-use statistics, to recover how the integrated uses of land were articulated by the inhabitants. Historical images can help us in this task. We can see in Figure 5 a comparison of two photographs taken circa 1908 and 2012 from the same place in Figaró-Montmany, showing a section of the lateral valley of Can Oliveres. We can see an apparent reforestation today contrasting with the lower woodland coverage at the

\footnotetext{
32 We omit the data taken from the livestock census kept at the municipal archive from 1861 to 1951-an indicator in itself of the maintenance of this activity - due to its low reliability. They repeated the exact same quantities of each type of cattle over several periods, leading us to suspect tax fraud. This is confirmed for 1951, when the comparison between the individual statements signed by each breeder and the final list sent to the authorities reveals that there were far more beats than officially declared. In these official lists livestock had to be ascribed to the municipality where their owner resided. Leasing of pastures or animals through partnership contracts were common verbal agreements which offered many opportunities for tax evasion.
} 
beginning of the twentieth century, particularly along the slopes of the hills on the left side of the images. Just above the column of smoke coming from the locomotive, the effects of large forest clear-cuttings can be observed circa 1908. The contrast becomes even more apparent when comparing the hilltops in the background of the images. While in 2012 these are totally wooded, in 1908 most of these lands located between 500 and 600 metres in altitude appeared to be open spaces, probably used as pasturelands. After the abandonment of extensive cattle grazing they became spontaneously reforested. 
FIGURE 5. The lateral valley of Can Oliveres, also known as Sots Ferèstecs or 'Dark Vales', seen from Figaró-Montmany circa 1908 and 2012.

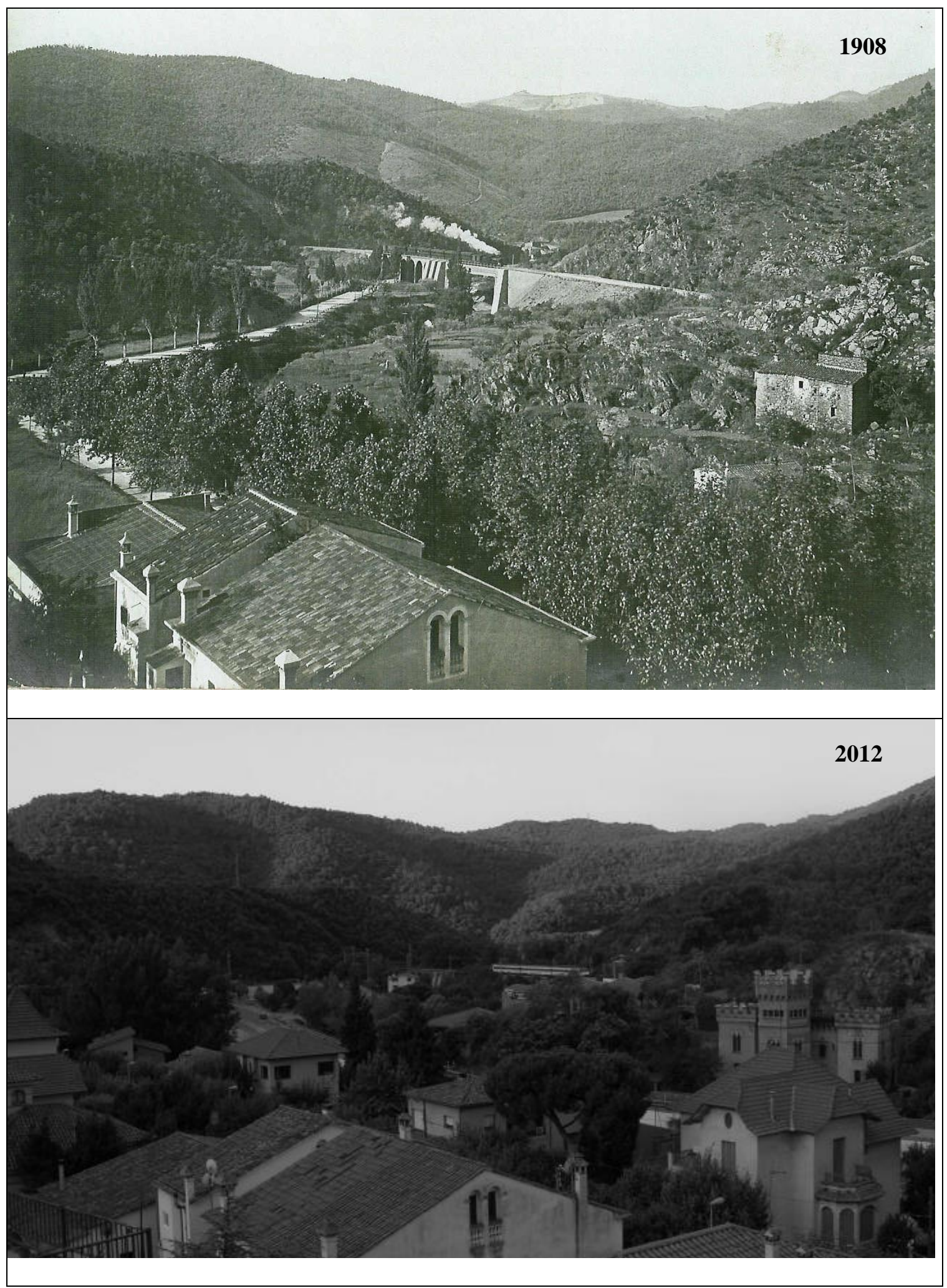

Sources:

Personal archive of Enric Tello. 
The cadastral map of Figaró-Montmany drawn in 1949 allows the identification of pasturelands and croplands that extended in a flat corridor that lay between two rows of cliffs in the Cingles de Bertí and Castellar - in spite of its clear bias towards recording forestry uses and its tendency to omit pasturelands, counting them as forests or wastelands. Pastures also appeared scattered in some open and flatter spaces located higher in the Vallcàrquera valley and other parts of the Montseny massif. We can see some of the same land, although in a more blurred way, with the land cover geo-interpretation made from aerial photographs taken by the US army in 1956 - in this case mixing former meadows or grazing areas with abandoned croplands (Figure 6).

FIGURE 6. Land-uses and land cover types in Figaró-Montmany:

According to the cadastral map of 1949

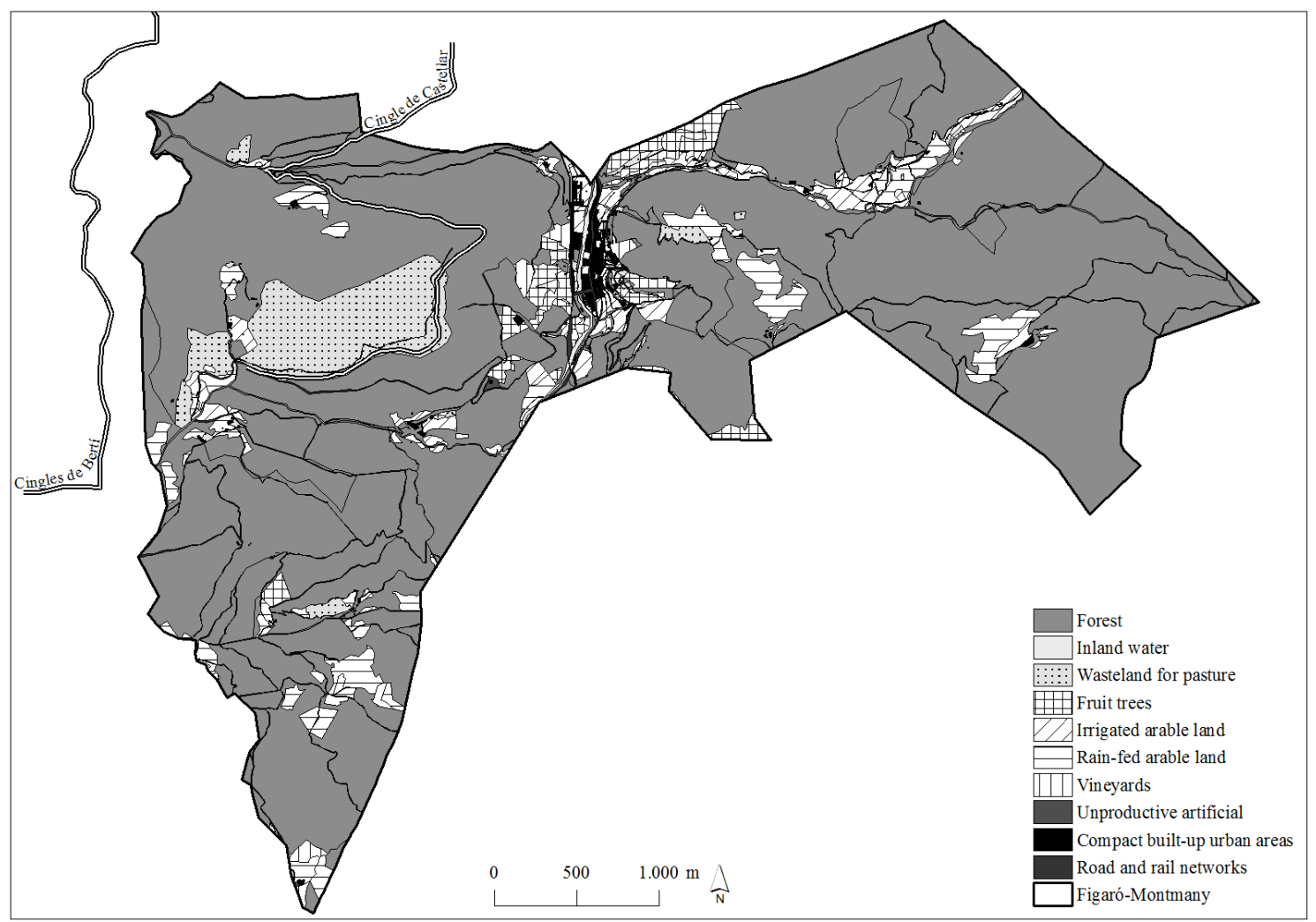


According to the aerial photographs of 1956

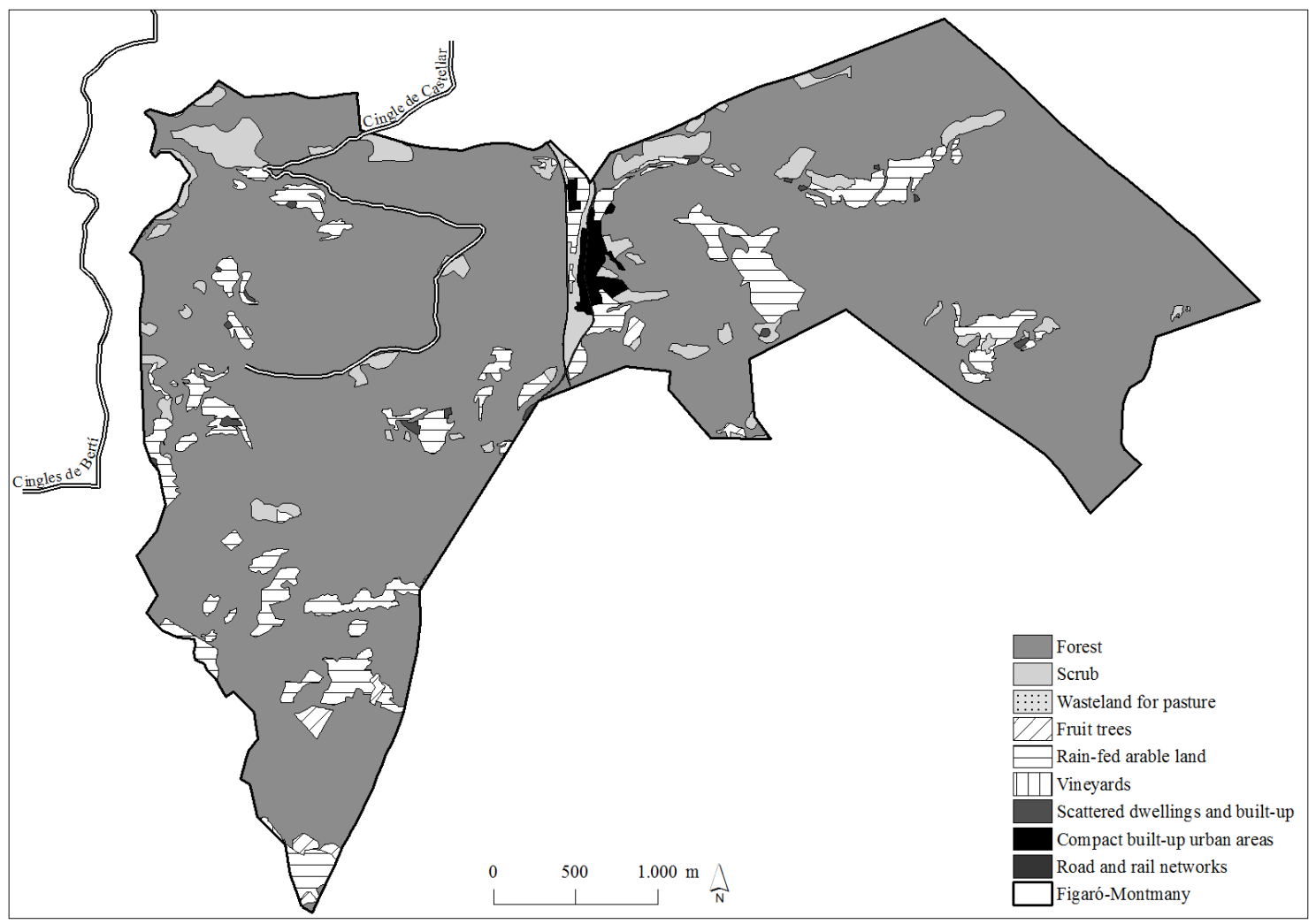

According to the satellite images of 2005

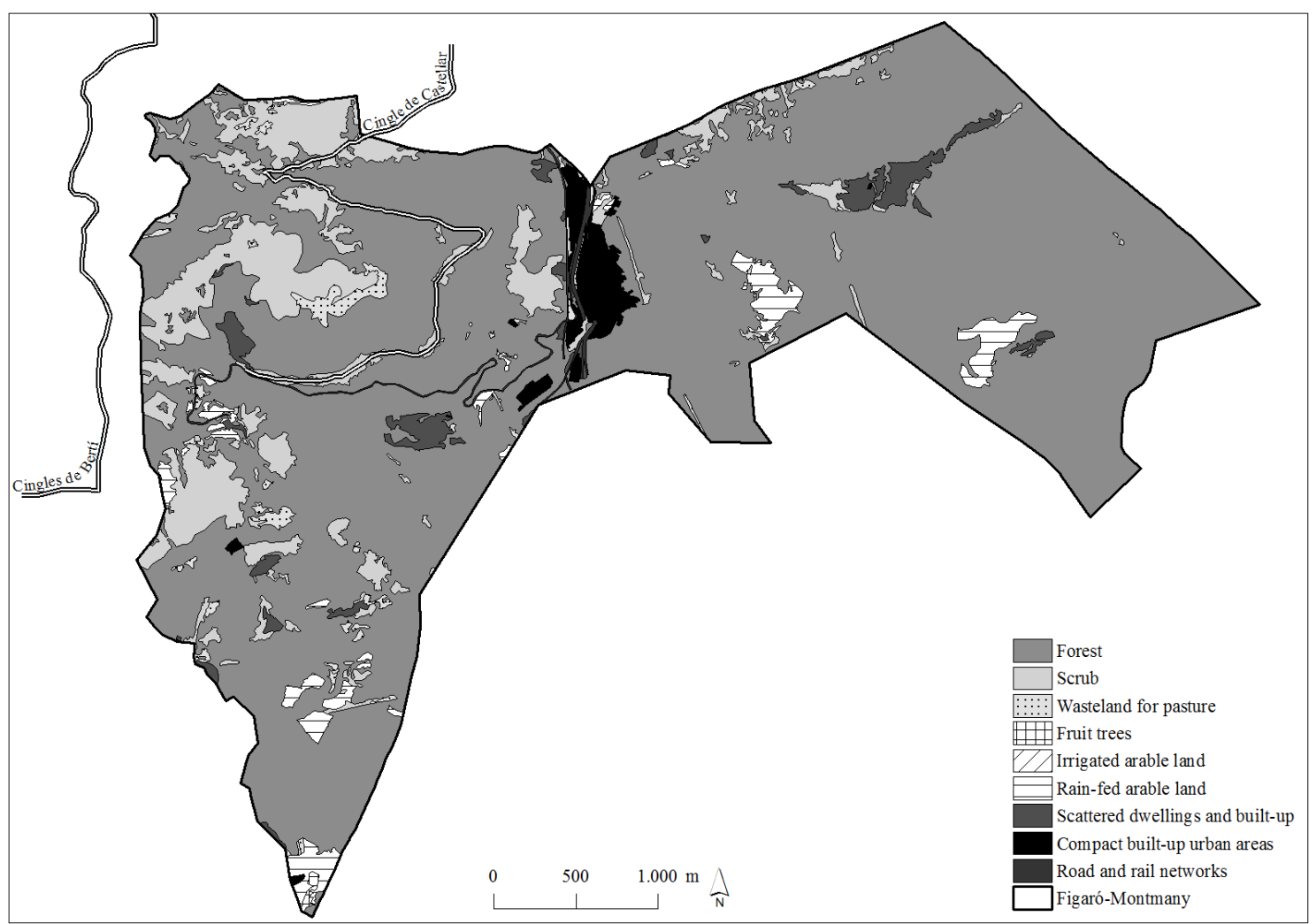


Sources:

Drawn by Natàlia Valldeperas and Anna Ollés from the cadastral map of 1949 kept in the Historical Municipal Archive of Figaró-Montmany with the funds provided by the Batista i Roca Grant 2010PBR00002; from the GIS digital layers of the geo-interpretation of the aerial photographs taken 1956 by the United States Army provided by the CREAF and adapted at the IERMB; and by Natàlia Valldeperas and Anna Ollés from the GIS digital layers of the geo-interpretation of the satellite images, also adapted at the IERMB.

However, by comparing the two land cover maps of 1949 and 1956 we can note considerable differences, when it is implausible that in only seven years land uses had experienced large changes - such as an spontaneous reforestation that would require several decades to grow up. Only shifting and overlapping land-use categories may explain the 'disappearance' in 1956 of the above-mentioned big unit of grazing land in the Cingles de Bertí area, shown in yellow as 'wasteland for pasture' in the 1949. In the 1901 novel Els sots ferèstcs Raimon Casellas described the local herdsmen driving their flocks in the shaded sides -called 'obaga', 'baga' or ' $b a c$ ' in Catalan - at the edge of the woods of oaks and holms precisely in this corridor along the Cingles de Bertí, while according to him the charcoal-makers looked for other open spaces on the sunny sides of the same areas. ${ }^{33}$ This spatial distribution makes sense, and fits with what we can see in Figures 5 and 6. Throughout the topography of the massif, from the Congost River upwards, there was a first level of slopes covered with pines mainly exploited for lumber and firewood - like the clear cuts shown above the locomotive in the picture taken in

33 R. Casellas, Els sots feréstechs (Barcelona: Llibrería de Francisco Puig, 1901), 11, 15, 18 and 20. This novel ('Dark Vales', according to the English translation by Alan Yates edited by Eva Bosch and issued in Dedalus Books in 2014) contrasted the 'untamed' and indomitable nature of the inhabitants of those mountains in a lateral valley of Figaró-Montmany, with the Catholic fervour of their parish priest. The author had lived in this small valley when he was a child, and some of the characters or events included in the narrative evoked real people and historical facts (see J. Castellanos, foreword to Raimon Casellas, Els sots ferèstecs. Barcelona: Laia, 1980). In the 1820s those villagers refused to pay tithes, and they even assaulted the rectory obliging the priest to run away to the Montmany Township. 
1908 (Figure 5). Then, above the first row of cliffs, this corridor of flatter lands was covered by a peculiar mosaic of croplands, pasturelands, woodland-meadows and woodlands of oaks and holms. Woodsmen regularly removed firewood in these sparse forests where charcoal-makers also pruned their branches for their kilns, usually located in bare or rocky lands as near as possible to a spring in order to better control the fire.

Thanks to this multiple use, the oaks and holms of these woodlands probably became taller and more distant from one another. Sunlight could penetrate the canopy allowing the grassy layer of the land to grow fescues or thatching grasses to be eaten by flocks of sheep and goats. These new types of Mediterranean woodland-meadows increased the spatial heterogeneity of forestlands inside a mosaic with cropland and scrubs, as well as the height and age differentials of the remaining trees. Due to the edge effect generated by this combination of open and wooded mosaics, connected with a network of streams, a wide set of microhabitats was offered to many plants (e.g. orchids) and animals from butterflies to partridges, crested larks, rabbits, hares and their predators. ${ }^{34}$

This also helps to explain why pasturelands tended to fade out in the landuse statistics and maps drawn up by people with a forestry-oriented mind. When traditional livestock breeding was stopped at the same time as charcoal-burning and firewood collection, the whole system of multiple and integrated use of forestlands and pastures suddenly collapsed. This can be seen by comparing the 1949 or 1956 land-use maps with land covers seen in 2005 (Figure 6). The big grazing area we can see in the 1949 map has in 2005 turned into scrubland, except in some remnant edges where there are still open meadows (coloured in yellow on the map).

\footnotetext{
34 The effects of ongoing land cover changes on the habitat of other plant and animal species, in a context of global warming, are analyzed in Catalonia by J. Peñuelas, I. Filella, and P. Comas, 'Changed plant and animal life cycles from 1952 to 2000 in the Mediterranean region', Global Change Biology 8 (2002): 531 - 544; J. Peñuelas and M. Boada, 'A global-change induced biome shift in Montseny mountains (NE Spain)', Global Change Biology 9 (2003): 131 - 140; C. Stefanescu, S. Herrando and F. Páramo, 'Butterfly species richness in the north-west Mediterranean Basin: the role of natural and human-induced factors', Journal of Biogeography 31 (2004): 905 - 915; C. Stefanescu, J. Peñuelas and I. Filella, 'Butterflies highlight the conservation value of hay meadows highly threatened by land-use changes in a protected Mediterranean area', Biological Conservation 126 (2005): 234 246; and I. Otero, M. Boada, A. Badia, E. Pla, J. Vayreda, S. Sabaté, C.A. Gracia and J. Peñuelas, 'Loss of water availability and stream biodiversity under land abandonment and climate change in a Mediterranean catchment (Olzinelles, NE Spain)'.
} 


\section{ORCHIDS AS BIOINDICATORS OF GRAZING AREAS LEFT ABANDONED}

Nevertheless, the traditional mosaic once maintained by multiple uses has left a lasting imprint on this cultural landscape, to which we can add another clue from modern fieldwork: the location of orchids that can be used as a landscape bioindicator of the loss of meadows and open grazing areas. Here we make use of evidence not usually available to historians, but that also highlights very directly the ecological consequences of the processes driving shifts in land use. European orchids cannot grow under a closed canopy, but need sunlight. They cannot live inside a thick forest - except Limodorum abortivum, Cephalanthera rubra and, sometimes, species of Epipactis. On the other hand, to germinate their seeds they need a mycorrhiza which it is not present in ploughed soils. Finally, orchids are perennial plants that cannot grow in arable land. Thus Mediterranean orchids are mainly present in uncultivated open spaces, making them an interesting bioindicator of former woodland-meadows and other pasturelands interwoven with agro-forest mosaics now abandoned and evolving towards continuous land covers of scrubs and woodlands (Figure 7). ${ }^{35}$

35 The association of former grazing pastures or grassy layers at the edges of woodland-meadows with orchids has been pointed out in Italy by R. Cevasco and D. Moreno, 'Paesaggi rurale: alle radici della biodiversità/Rural landscapes: the historical roots of biodiversity', in M. Agnoletti (ed), Paesaggi Rurali Historici. Per un Catalogo Nazionale/Historical Rural Landscapes. For a National Register (Roma-Bari: Laterza, 2010), 128. 
FIGURE 7. An example of Mediterranean orchid in the remaining meadows and other open spaces of Figaró-Montmany: the Ophrys catalaunica

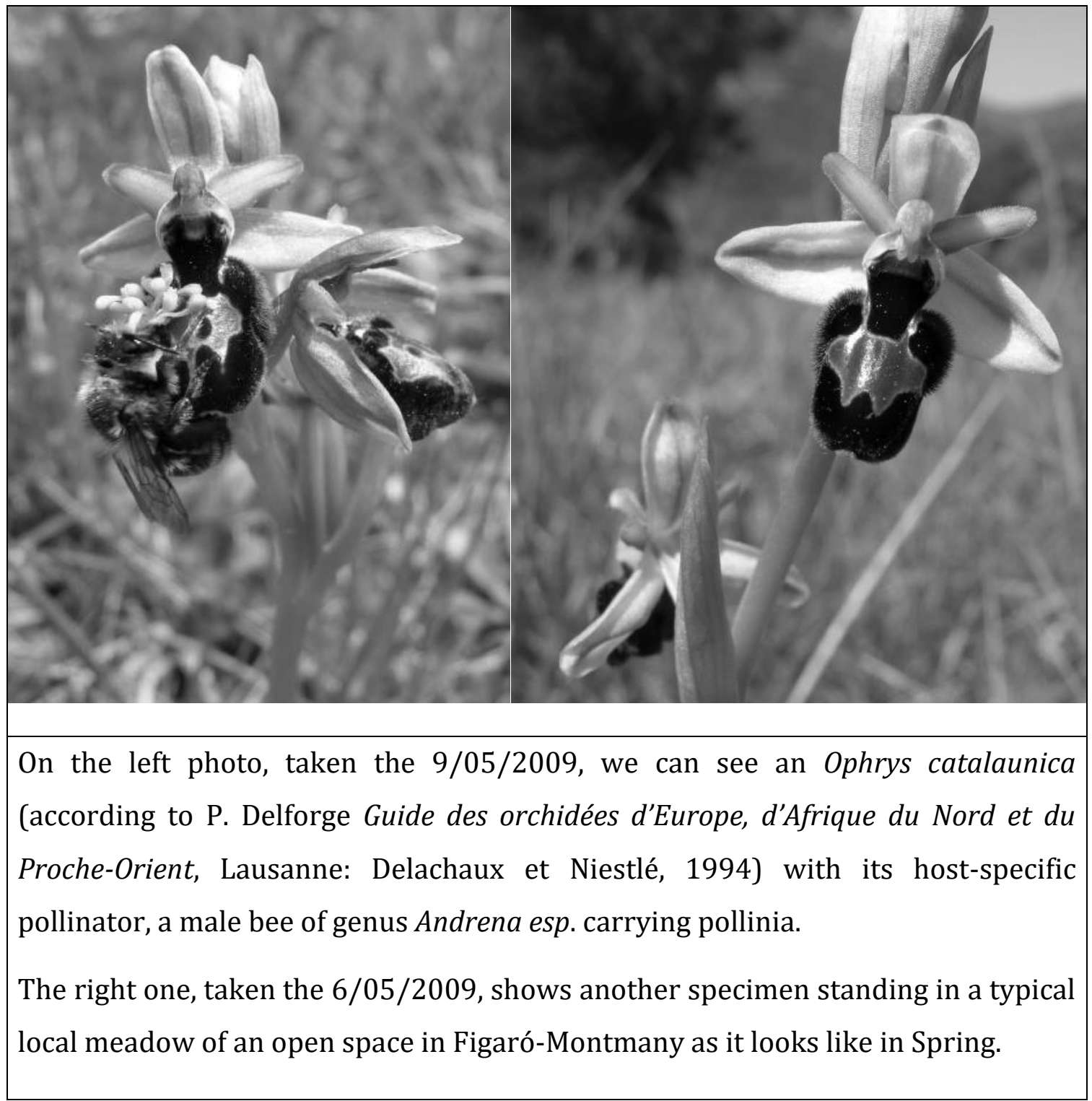

Sources:

Personal archive of Paul Wilcox.

A systematic sampling conducted between 2007 and 2012 has identified up to 35 different species of orchids in Figaró-Montmany. We can see in Figure 8 how their locations tend to fit with those areas that we have considered to be former pasturelands or abandoned crops. Most of them appear in the abovementioned 
flatter corridor between the two rows of cliffs of the Cingles de Bertí and Cingle de Castellar, while the rest tend to be located in margins of roads or trails that go up towards those crags - which had become a kind of relict linear meadows. We should not view such a great richness of orchid species in these areas only in narrow terms, but also as an indicator of the likely presence of high biodiversity and an environment that deserves to be studied and valued.

FIGURE 8. Locations of the Mediterranean orchids found in Figaró-Montmany in 2007-2012

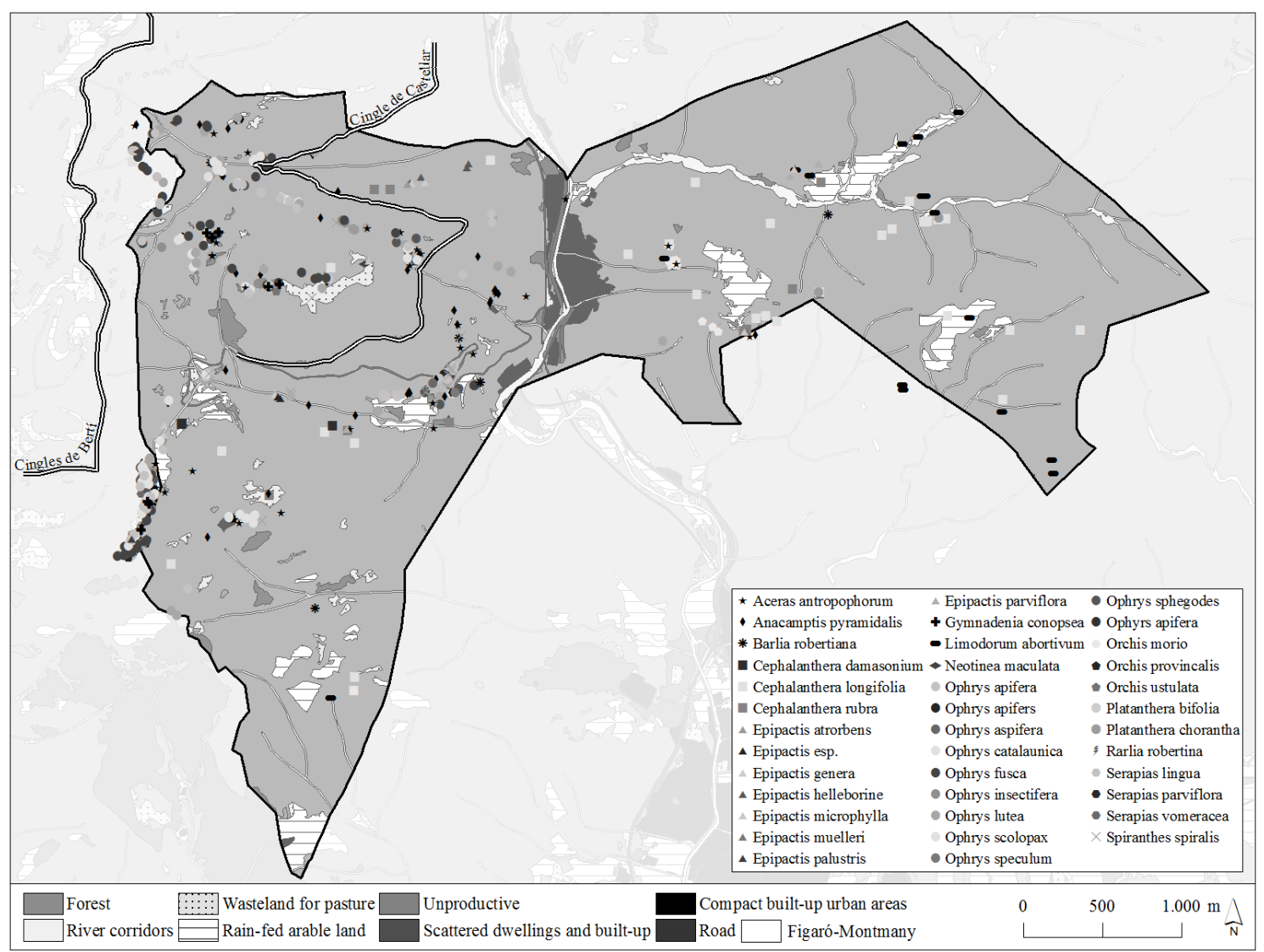

Sources:

Drawn out of the sampling collected and location maps geo-referred by Paul Wilcox and adapted at the IERMB. 


\section{CONCLUDING REMARKS}

The border between the townships of La Garriga and Figaró-Montmany has been an edge environment throughout its long history from 1850 to 2005, the period studied in this article. It was a border of an agricultural plain confronted with a mountainous area of forestry and livestock-raising in the mid-nineteenth century, and it remains a border between a metropolitan edge and two natural protected sites today. In spite of its changing nature, the contrast between widespread land cover changes experienced in La Garriga and the seeming immobility of mainly woodland land cover in Figaro-Montmany means that the topography and ensuing natural thresholds have created a very long-lasting continuity in the environmental history of this area. These natural endowments established an edge environment at the beginning of our story and still form the limit to the boundary of the BMR.

This edge environment also brings into contact the two main opposite but related dynamics that characterize landscape change throughout Catalonia and great parts of Mediterranean Europe: intensification and abandonment. We find some very global trends in a very site-specific context. Studying land cover changes in small places like this, and their ecological and landscape impacts, may provide useful knowledge to make and implement wiser private choices and better public policies aimed at a more sustainable future not only here, but everywhere.

The most salient landscape ecological impact of these long-term land use changes has been similar on both sides of the environmental edge: the loss of landscape mosaics. No doubt, these traditional mosaics were different in the plains or in the mountains. In the Vallès plain they interwove cereal cropping with vineyards, olive orchards and other tree crops together with patches of woodland, scrubland and pastureland into an agricultural land matrix. In the mountains, a woodland matrix of holm oaks and pines became cleared and opened up by timber or firewood extraction, as well as by pruning of branches for charcoal making, 
creating a mixture of sparse forest articulated with open spaces of grazing meadows, croplands and scrubs. Both types of mosaic interlinked, and jointly they played an important role in supporting biodiversity as ecologically functional cultural landscapes. Unfortunately, although a large proportion of it was transformed into natural protected sites, the abandonment of the integrated management of forests, livestock grazing and cropland has led to a significant loss of these cultural mosaics.

The diversity of traditional agro-forest mosaics offered more habitats to different species and created a greater number of ecotones which, in turn, also provided more opportunities to diverse edge species. Therefore, species richness used to be higher in these patchy landscapes while the populations of each species were lower. Provided that the mobility of all these species and their capacity to interact throughout the land matrix were not prevented by insurmountable barriers -that might reduce and isolate their populations up to the point of endangering them with extinction - , the land cover diversity of traditional agroforestry mosaics could host a greater deal of biodiversity than the more uniform land covers found nowadays. ${ }^{36}$ The Mediterranean orchids testify to the ecological virtue of a world that no longer exists, whose land-use management relied on an intermediate pattern of ecological disturbance through cultural agro-forest mosaics. No doubt, natural protected sites are important achievements for biological conservation, but as long as they remain isolated and unmanaged, this will not be enough to prevent biodiversity loss. ${ }^{37}$

\footnotetext{
${ }^{36}$ In a forthcoming article we are going to use landscape ecology metrics to undertake a deeper evaluation of the ecological impact of this loss of landscape mosaics (see footnote 22). A state-ofthe-art on the ecological 'edge effect' of patchy landscape mosaics can be found in C. Murcia, 'Edge Effects in fragmented forests: implications for conservation', Trends in Ecology and Evolution 10 (1995): 58 - 62; and more recently, in K.A. Harper, S.E. MacDonald, Ph.J. Burton, J. Chen, K.D. Brosofsfe, S.C. Saunders, E.S. Euskirchen, D. Robert, M.S. Jaiteh and P.-A. Esseen, 'Edge Influence on Forest Structure and Composition in Fragmented Landscapes', Conservation Biology 19 (2005): 768 - 782. From an agricultural approach, see D. Gabriel, I. Roschewitz, T. Tscharntke and C. Thies, 'Beta diversity at different spatial scales: plant communities in organic and conventional agriculture', Ecological Applications 16 (2006): 2011 - 2021. In our Catalan context see M. Guirado, J. Pino and F. Rodà, 'Understorey plant species richness and composition in metropolitan forest archipelagos: effects of forest size, adjacent land use and distance to the edge', Global Ecology and Biogeography 15 (2006): 50 - 62.

${ }^{37}$ As a general approach to these processes, see T.G. Benton et al., 'Farmland biodiversity: is habitat heterogeneity the key?'. See also U. Reier, E.-L. Tuvi, P. Meelis, R. Kalamees and M. Zobel, 'Threatened herbaceous species dependent on moderate forest disturbances: A neglected target for ecosystem-based silviculture', Scandinavian Journal of Forest Research 20 (2005): 145 - 152. The
} 
Therefore, just relying on the legacy of land covers inherited from the past and waiting for their 're-naturalization' through abandonment is not enough to preserve biodiversity. The orchids' attempt to survive year after year in FigaróMontmany, while their microhabitats are fading out, becomes like a silent cry that calls upon us to search for a more sustainable land-use management. The open question is whether we will decipher their cries in a fast changing landscape, while we remain on our urban side of the edge.

\section{ACKNOWLEDGEMENTS}

This work has been supported by the Batista-i-Roca Grant 2010PBR00002 funded by the Anglo-Catalan Society through the Catalan Research Agency AGAUR, and also with the research project HAR2012-38920-C02-02, Sustainable farm systems and transitions in agricultural metabolism: social inequality and institutional changes in Spain, 1750-2010, (http://www.ub.edu/histeco/p2/eng/) funded by the Spanish Ministry of Economy and Competitiveness. Both projects are included in the Partnership Grant SSHRC- 895-2011-1020 on Sustainable farm systems: long-term socio-ecological metabolism in western agriculture funded by the Social Sciences and Humanities Research Council of Canada. The corresponding author, Enric Tello, has also benefited from a six-month stay in 2013 as a visiting professor in the Institute of Social Ecology at the Alpen-Adria Klagenfurt University in Vienna. The comments made by two anonymous reviewers have helped to improve the text.

edge character of the orchids' habitats is pointed out, among others, by W.S. Alverson, D.M. Waller and S.K. Solheim, 'Forest to Deer: Edge Effects in Northern Wisconsin', Conservation Biology 2 (1988), 353; T. Kull and M. Hutchings, 'A comparative analysis of decline in the distribution ranges of orchid species in Estonia and the United Kingdom', Biological Conservation 129 (2006): 31 - 39; S.F. Jackson, K. Walker and K.J. Gaston, 'Relationship between distributions of threatened plants and protected areas in Britain', Biological Conservation 142 (2009): 1515 - 1522; and M. B. García, D. Goñi and D. Guzmán, 'Living at the Edge: Local versus Positional Factors in the Long-Term Population Dynamics of an Endangered Orchid', Conservation Biology 24 (2010): 1219 - 1229. 